\title{
RENTAS SEÑORIALES EN EL MARQUESADO DE LLOMBAI (XVI-XVII)*
}

\author{
Elia GozÁlbez Esteve \\ Universidad de Alicante
}

\begin{abstract}
Resumen
Este artículo analiza las diversas modalidades que presentaban las cargas que recaían sobre los vasallos del Marquesado de LLombai, con especial atención a la etapa anterior a la expulsión de los moriscos. Repartida entre cuatro lugares, integrantes de dicho marquesado, la población cristiana y mudéjar-morisca estuvo sometida a una fiscalidad señorial diferenciada y muy heterogénea, que determinó una composición de la renta muy compleja y variable. Queda aquí de manifiesto la amplitud de derechos y las modificaciones que se fueron introduciendo en las formas de exacción a lo largo del tiempo, en gran medida a través de concordias con los vasallos.
\end{abstract}

Palabras clave: Señorío, LLombay, Duques de Gandía, renta señorial, moriscos.

\begin{abstract}
This article analyzes the diverse modalities that presented the loads that fell on the vassals of the Marquisate of LLombai, with special attention to the previous phase to the expulsion of the Muslim. It distributed among four places, members of said marquisate, the Muslim and Christian population was submitted to a manorial fiscality differentiated and very heterogeneous, that determined a composition of the variable and very complex income. It remains here of manifesto the amplitude of rights and the modifications that were themselves introducing in the methods of levying through the years, in great measure through agreements with the vassals.
\end{abstract}

Keywords: Señorío, LLombai, Dukes of Gandía, Muslim, manorial income.

\footnotetext{
En este artículo se hacen abundantes referencias a mi tesis doctoral Análisis de un señorio valenciano: El marquesado de Llombai (1990), dirigida por don Antonio Gil Olcina y basada en la consulta exhaustiva de la riquísima documentación sobre dicho señorío existente en la sección de Osuna del Archivo Histórico Nacional (AHN). Así mismo, numerosas alusiones a publicaciones mías anteriores, desde 1983, y posteriores a la defensa de aquella.
} 
Ubicados en la Ribera Alta del Júcar, concretamente en el Valle de Alcalá, los cuatro lugares que llegaron a formar la «Foia» y baronía de Llombai -Catadau, Alfarb, Llombai y Aledua- tuvieron su origen en el reparto que hizo don Jaime I de las tierras conquistadas entre sus caballeros ${ }^{1}$. A través de posteriores donaciones, herencias y ventas, dichos lugares fueron unificados jurisdiccionalmente por Don Aymerich de Centelles; y a finales del siglo XV, mediante sucesivas compras, Don Juan de Borja I logró la unidad territorial anexionándolos a la casa Ducal de Gandía. Tan solo unas décadas más tarde (1530) Carlos V concedió a Don Francisco de Borja el título de Marqués de Llombai, quedando instituido en esta fecha el Marquesado de Llombai².

Como es sabido, el emplazamiento de los mudéjares valencianos, en relación con el de los cristianos, responde invariablemente a la situación de vencidos; por tanto, en el centro donde se ejerce una función administrativa, política o comercial, en sus formas más complejas, hemos de encontrar siempre cristianos viejos. Estas características se dieron cita en Llombai, centro administrativo alrededor del cual giraban los lugares de Catadau, Alfarb y Aledua, con una población exclusivamente mudéjar.

A nuestro entender, las circunstancias que rodearon el señorío (origen, ubicación, población mixta, etc.), además de darle una identidad propia, modélica en cuanto a su formación y desarrollo, sugiere varios temas de debate. En primer lugar, la posibilidad de analizar el trato del señor a sus vasallos de diferente credo; en segundo lugar, la relación, en el grado que hubiese, entre estas dos comunidades; pero, sobre todo, la diferente tributación existente entre ambas.

Pese a ser poco frecuente la coexistencia de las dos comunidades en núcleos de población reducida, en Llombai el escaso número de habitantes no fue un impedimento para que la universidad cristiana y la aljama mudéjar, más tarde morisca, compartieran un mismo espacio geográfico, aunque con diferente realidad socio-económica. Tal y como era de esperar, hubo similitudes entre ambas comunidades; por lo que quizá no fuera razonable enfatizar las diferencias entre dos pueblos que tantas cosas comunes tuvieron que compartir. Pero también existieron diferencias tan insalvables que ni siquiera la convivencia de siglos lograron neutralizar; situación que no mejoró la actitud del Duque de Gandía, el cual se mostró ajeno e indiferente a esta dualidad, al estar más preocupado por conservar, y en muchos momentos recuperar, su patrimonio, que en intervenir en una compleja situación social que en muchos aspectos le era ventajosa. En el señorío que nos ocupa, la persistente discriminación fiscal y la divergencia

1. AHN: Sección Osuna, Leg. 722-659, año 1238, 28 julio, Asedio a Valencia: Va inserto en un traslado de 1259. Ferrando y Francés, Antonio: Llibre del Repartiment del Regne de Valencia, n. ${ }^{\circ} 2238-549$ Lombay y Catadau. N. ${ }^{\circ} 325-2225$, Alfarbe. N. ${ }^{\circ} 208$ (año 1237) Aledua, n. ${ }^{\circ} 1099$ (año 1239) Aledua.

2. ARV: Sección Real Audiencia. Libro 496 fol. 204 a 206 año 1393 (anulación de retroventa). AHN: Sección

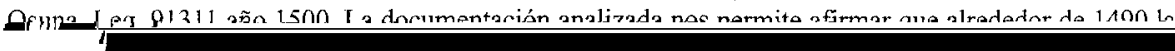


existente entre estas dos comunidades queda de manifiesto en su diferente aportación a las rentas.

A pesar del desarrollo alcanzado por los estudios sobre régimen señorial valencia$n^{3}$, escasean los referentes a la época anterior a 1609 , de modo que conocemos mejor las condiciones a que estaban sometidos los cristianos a raíz de la repoblación, que las que regían antes de la expulsion de los moriscos. $\mathrm{Y}$, obviamente, conocer la fiscalidad de los mudéjares-moriscos es de suma importancia para calibrar mejor las valoraciones que se han hecho acerca de las consecuencias de la expulsión: ¿endurecimiento?, ¿reestructuración?. Dentro de este contexto, tan sugerente, el objetivo del presente trabajo es abordar detalladamente el origen y composición de las rentas en un señorío con presencia de población mudéjar y cristiana. Ahora bien, la propia dinámica de las rentas se presta a confusiones, en gran medida como consecuencia de transacciones y concordias no siempre suficientemente documentadas, además de tratarse de cuatro lugares que en su origen tuvieron distintos señores que aplicaron distintos modos de tenencia sobre la tierra y diferente tributación, lo cual obstaculiza el propósito enunciado.

Las rentas en el marquesado evolucionaron según el esquema habitual, desde rentas en trabajo, hasta rentas en dinero, pasando por las rentas en especie. No obstante, la riqueza de información referente a determinados tributos sobrepasa lo que podríamos denominar usual, por lo que su contenido merece ser conocido. Para clasificar dichas rentas, me he ceñido a la ya clásica división de: rentas agrarias, ingresos derivados del ejercicio de las prerrogativas jurisdiccionales, y en rentas generadas en virtud de la relación vasallática. Sin embargo, el desarrollo de semejante intento también ha resultado inviable en toda su amplitud. Posiblemente, en ello ha influido la existencia de ingresos perdidos en el tiempo cuyo origen es difícil determinar, con significados distorsionados por el paso de los siglos. Pero esta circunstancia no es la decisiva a la hora de hacer fracasar una clasificación tripartita como la anunciada, sino el hecho de que sea fundamentalmente imposible; pues, como ha hecho notar Alain Guerreau ${ }^{4}$, lo que caracteriza la relación entre señor y vasallo es un «dominium» y este no es posible reducirlo a nuestras categorías actuales.

Por razones de espacio no podemos detenernos a profundizar en la configuración de las posibles diferentes formas de propiedad de la tierra; tan solo apuntar que nos encontramos ante un señorío cuyas tierras durante los siglos XV y XVI estuvieron explotadas, mayoritariamente, mediante el establecimiento a censo enfitéutico, con excepciones que no parecen tener gran importancia en el conjunto, ya que apenas hay referencias a tierras francas, o sea, propiedad de particulares que no reconozcan el dominio eminente y directo del señor. Aunque la documentación señorial -que constituye la principal fuente del presente trabajo- no sea la más adecuada para estudiar

3. BERNABÉ GL, David: «Quince años de estudios sobre el régimen señorial valenciano en la Edad Moderna», II Congreso Internacional sobre Señorio y Feudalismo en España. Zaragoza, 2004 (en prensa).

4. Guerreau, Alain: El feudalismo. Un horizonte teórico, Ed. Crítica, Barcelona, 1984. 
las tierras francas, los datos disponibles permiten apuntar que se trata de un señorío en donde, en un primer momento, casi la totalidad de la tierra perteneció al señor, por lo que las escasas tierras francas existentes parecen tener su origen en concesiones privilegiadas, como es el caso que obra en favor del alamín de Catadau a comienzos del siglo $\mathrm{XV}^{5}$ o las dos casas del baile y las tierras de la Iglesia, según las cuentas del colector en $1538-43^{6}$.

Además, los señores debieron establecer aquí pronto las tierras, en todo caso antes del siglo $\mathrm{XV}^{7}$, dividiéndolas en «heretats» explotadas por censatarios. En un principio, en la «Foia» y baronía de Llombai los señores se reservaron una parte de dicha tierra, la cual gestionaron de forma directa. Inicialmente esta debió tener cierta importancia, como lo demuestra la temprana exigencia de jornales, francos o remunerados, pero obligatorios para los vasallos, normalmente dedicados a la viña, tal y como se plantean en los servicios personales. Paulatinamente esta reserva señorial de viña y de otros cultivos también fue acensuada, según consta en los informes sobre rentas de comienzos del siglo XV. Por ejemplo, los mudéjares de Aledua pagaban un censo anual por unas viñas, concretamente por 22 hanegadas, que antes fueron reserva señorial, pues así lo hace constar el señor al señalar «la cual era mía»; de igual forma y en términos muy similares los de Catadau también pagaban un censo por «la vinya que solía esser del senyor». Otros ingresos que el señor recibía podían proceder indistintamente de un censo o de un arrendamiento, pero la falta de precisión en la documentación genera cierta duda. Así, por ejemplo, es difícil precisar a qué obedecían los tres sueldos satisfechos «per l'ort que esta damunt del castell», o los cuatro sueldos que pagaba Obaydal Nonem «per les huit fanecades de la vinya del senyor», o los dos sueldos que «pagua Obaydal Alaycat per cuatre fanecades de la vinya del senyor» ${ }^{8}$.

Pese a estas concesiones privilegiadas o a la incidencia de los arrendamientos sobre parte de ellas, los sucesivos señores siempre mantuvieron bajo su dominio algunos huertos cuyo objeto, presumiblemente, era abastecer la despensa señorial de productos perecederos. Pero el sentido práctico se imponía y las huertas señoriales fueron arrendadas cuando las ausencias del señor hicieron inútil aquella función. Por ejemplo, en 1403 se arrendó el huerto de Llombai por 3 libras y 15 sueldos y el de Alfarb por 12

\footnotetext{
5. AHN: Sección Osuna, Leg. 1028. A comienzos del siglo XV en Catadau se establece a Jafet Abzeyt dos heredades y media de tierras y viñas sujetas a fadiga y luísmos y de «les dos heretats e hun quarto, e que sia franch de hun quarto. Al alamin de Catadau una heredad y le deja francha media heredad».

6. GOZÁLBEZ ESTEVE, Elia: «Cristianos mudéjares y moriscos en el marquesado de Llombay», Revista de Historia Moderna, N 17, Alicante, 1998-99, pág.-195-218. AHN: Sección Osuna, Leg. 587-53. Gastos $1528-43,1530$ «se me han de dar 18 sueldos por la peyta de dos casas que tiene el Bayle y que su senyoria las hace francas». 1541 «Por las tierras perdidas por el río de Llombai y Aledua y por las tierras de la Iglesia y dos casas francas del baile 2L. 3s. 3d.».
}

7. GozÁlbez Esteve, Elia: Análisis de un señorío..., Tesis cit.

8. AHN: Sección Osuna, Leg. 1028; Leg. 937, año 1540. 
sueldos; y en fechas inmediatas a la expulsión se valoró en 25 libras el arrendamiento del huerto del señor en Llombai y Alfarb9.

A partir de estos datos y de otros un tanto ambiguos es muy difícil valorar la evolución de la renta agraria, pues seguramente la extensión de estos huertos varió a lo largo del tiempo, bien fuese por la enajenación de parte de ellos o porque el señor adquiriese nuevas tierras en el seno de su propio señorío. Cabe citar que a mediados del siglo XVI (1540) el señor compró nada menos que 164 anegadas de tierra en Alfarb para plantar viñas, sin que la documentación consultada indique quien o quienes fueron los vendedores, y además una extensión indeterminada de tierra destinada al cultivo de moreras, cuyo coste de acondicionamiento durante los años inmediatos (1541-1543) rondó las 128 libras $^{10}$.

Recordemos que aunque el sistema enfitéutico se impuso desde sus inicios en la «Foia» y baronía de Llombai, su aplicación no simplifica el contenido de las rentas en los siglos XV-XVI debido a la confusión de los conceptos impositivos, cuyo origen y significado se entremezclan. Tal y como expone Pla Alberola, en ocasiones también faltan en estas valoraciones contabilizar ingresos de cobro más aleatorio como pueden ser los luísmos, partidas cuya percepción se reservaba al señor, así como las penas por encima de 60 sueldos y las composiciones u otros ingresos que eran asignados como honorarios, sin hablar de la imposibilidad de valorar monetariamente los servicios personales ${ }^{11}$.

En resumen, estamos ante un señorío que, como la mayoría de los valencianos, en la estrategia seguida para su explotación, responde más al modelo normando estudiado por Guy Bois que al polaco analizado por W. Told Kula o al siciliano investigado por Aymard. Pero no vamos a entrar a analizar su rentabilidad, ya que lo que aquí nos proponemos es conocer el origen y evolución de unos tributos singulares, con notables convivencias entre los implantados tras la reconquista y los islámicos que sobrevivie$\operatorname{ron}^{12}$.

A pesar de estas limitaciones, para aproximarnos al conocimiento de las rentas, procedencia y significado, dividiremos su contenido en tres grandes bloques, a saber: las rentas percibidas por el señor en especie, las satisfechas en metálico y las azofras; no $\sin$ antes insistir una vez más en la distinta fiscalidad a que estaban sometidas las dos comunidades ubicadas en el señorío, ya que la tributación de los mudéjares-moris-

9. AHN: Sección Osuna, Leg. 1027-4. Año 1403. Leg. 582. Leg. 937/540-43. Leg. 1027/8. De igual forma y por similares conceptos, a mediados del siglo XVI se habla unas veces del huerto de Alfarb y otras del de Catadau.

10. AHN: Sección Osuna, Leg. 587-53. Gastos 1538-43.

11. Pla Alberola, Primitivo J.: «Benemejís y Señera ante la expulsión de los moriscos», en este mismo número de la Revista de Historia Moderna.

12. BoIS GUY: Crise du feodalisme: economie rurale et dimographie en Normndie orientale du debut du 14 siecle au milieu du 16 siècle; KULA, Witol: Teoria económica del sistema feudal, Siglo XXI, Buenos Aires, 1976; AYMARD, Maurice: «L'Europe Moderne: feodalites», Annales C.S.C.; Paris; vol. 36, $\mathrm{n}^{\circ} 3$, Mayo-Junio 1981. 
cos era diferente y superior a la de los cristianos, como a continuación vamos a tener ocasión de comprobar.

\section{ESTRUCTURA DE LAS RENTAS}

\section{1.- Prestaciones en especie}

El señor obtenía de sus vasallos rentas en especie principalmente por particiones, adehalas, «alcaydia», tercio diezmo y derecho de «fatra».

\section{1.- Particiones}

De forma muy generalizada, los especialistas en el tema sostienen que la diferencia de rentabilidad de unos señoríos a otros dependía en gran medida de que los señores participasen, o no, en la producción agraria; y de ahí su importancia.

Mediante este tributo en especie los señores compartían con sus vasallos los riesgos y además podían percibir sus rentas libres de inflación, sin grandes gastos y sin necesidad de estar pendientes de las explotaciones. A este respecto debemos considerar que los campesinos, además de entregar la parte alicuota de sus cosechas al señor, cuidando de hacerlo en las de mayor calidad, estaban obligados en muchas ocasiones a transportarla a sus costas a los puntos establecidos, graneros y casas señoriales ${ }^{13}$.

Para comprobar que la parte de la cosecha entregada fuese la exigida, en cantidad y calidad, se hacía el «alfarrasament», consistente en calibrar a ojo la producción de la cosecha en el campo. El término alfarrazar es de origen árabe y su cometido era realizado por expertos, generalmente representantes señoriales. Es de suponer que en Llombai en la elección de los expertos se procurara que fuesen cristianos viejos, tal y como se recomienda en la vecina Carlet, cuando se aconseja que este menester fuese ejecutado por su batle y el alamín acompañados por «dos bons homens christians»; o como en Benimámet, en donde se matiza que si los jurados fuesen moriscos se puede elegir una tercera persona, con la condición de que fuese cristiano viejo ${ }^{14}$. En última instancia, el alfarrazamiento siempre era llevado a cabo por quien el señor designara.

El hecho de alfarrazar las cosechas tenía una doble intencionalidad; valorar lo que correspondía al señor por partición y, si éste lo creía conveniente, conmutar en metálico dicho derecho, contabilizando los productos en arrobas. En Alfarb, por ejemplo,

13. COLAS LATORRE, Gregorio: «El régimen señorial en Aragón», Revista de Historia Jerónimo Zurita. $\mathrm{N}^{\circ} 52$, pág. 19.

14. AHN: Sección Osuna, Leg. 1028. Así lo indican expresiones tales como «per lo dret alfarraçament dels alfalsos per lo col-lector alami o jurats», «en tots els alfarrazaments sia lo balle o alcayt del senyor, si esser hi volrra o altri per lo senyor aquello aquells qui al dit senyor ploura o ordenara» (Alfarb) o «parteixen les vinyes al terç on les alfarrazar el alami e dos persones o aquells qui plaura lo senyor elegir». BeniteZ SÁNCHEZ-BLANCO, Rafael: «Las Cartas Pueblas del condado de Carlet y los conflictos sobre su aplicación», Saitabi, XXXXVI, 1986, pp. (Carta puebla de 1520); «Benimámet una baronía en la huerta de Valencia a fines del siglo XVI», V Simposio Internacional de Mudejarismo, Instituto de Estudios Turolenses, Teruel, 1991, pág. 256. 
tanto de la huerta como del rahal, una vez alfarrazada la vid, si el señor lo prefería, se podía sustituir la partición por 4 dineros por arroba: «deven dar lo terc de la verema, o per arrova de ço que sera alfarraçar quatre dines per arrova». Con respecto a las higueras, sucedía algo similar, pudiendo conmutar la partición por 1 sueldo 3 dineros la arroba. Además, se hacía imprescindible el alfarrazamiento de determinados cultivos forrajeros que se consumían en fresco o almacenados, exigiendo el señor, según los casos, que se le diese en verde (herbes) o en seco (blats): «si alfarraçen les herbes ço es ferraja, avena o dacca rroja o daça blanca pero selectio del senyor sí volrra la herba o el blat».

El denominado «dret de alfarrasament» era satisfecho indistintamente en metálico o en especie, y atañía y se exponía en los siguientes términos: «paguen per alfarraçaments de faves, panis, e per alfarraçaments de algunes erbes, de panis paguen panis, pero es voler del senyor si volrra les herbes o los blats» (Aledua). También podía suceder que el objeto de la estimación fuese la superficie cultivada, tanto en bienes sujetos a censo, como los de partición, por ejemplo en la viña, la alfalfa o el lino: así en Alfarb la partición del lino era de $1 / 3$ en el rahal y $1 / 4$ en la huerta y quedó conmutado por concordia, previo «alfarrazament»; en 5 libras por hanegada ${ }^{15}$. Debido a las características de los productos e intereses señoriales, no todos los frutos estaban sujetos a partición ni eran valorados por medio de alfarrazamiento.

El ingreso más importante de las rentas en especie fueron las particiones, aunque no todos los señores las consideraron rentables o viables. Los mismos duques de Gandía no las impusieron en sus lugares por igual, ya que, mientras en la huerta de Gandía éstas ocupaban un discreto lugar -según Ciscar Pallares- en Jaraco y Xeresa, con una estructura de las rentas diferente, se obtenían abundantes y altas «particiones en casi todos los productos agrícolas, lo que resultaba insólito y altamente beneficioso para las miras señoriales», calificando, el citado autor, de equilibradas las impuestas en la baronía de Castellón, en las cercanías del valle de Albaida, en Chella y en el marquesado de Llombai, donde se pagaba tercio diezmo y partición de la cosecha, además de regalías, carnage, luísmos y censos en dinero ${ }^{16}$.

En la «Foia» y baronía de Llombai, el señor percibía parte de la cosecha de sus vasallos, pero estas particiones no se mantuvieron inmutables. Los sucesivos señores fueron imponiendo sus criterios y don Ramón Castellá (1381), señor de Llombai y de la mitad de Catadau, mediante dos escrituras permutó antiguas particiones, junto con otras rentas en especie, por censos en metálico. ¿Modernización o simple estrategia? Resulta díficil de precisar, pero lo que sí podemos constatar, al menos, son las dificultades que en muchos aspectos acompañaron al campesinado en el siglo XIV, lo que determinó que la mayoría de los señores optaron por retener a sus vasallos, aunque para ello tuviesen que pactar o acceder a conmutaciones y moratorias.

15. AHN: Sección Osuna, Leg. 1028 (Catadau) «lo alfarrasament de Alfalços se pagua en diners a Nadal».

16. CisCAR PALLARES, Eugenio: La Valldigna siglos XVI y XVII. Cambio y continuidad en el campo valenciano, Diputación de Valencia, Valencia, 1997, pág. 191-209. 
El señor de Lombai, así mismo, acordó con sus vasallos mudéjares la paga anual de 60 sueldos, «per cascuna heretat de aquells, / ço es, per les terres, cases et vnyes, per raho de tots splets, los quals de aquí avant se colliran en les terres et possessions situades en lo regadiu de la orta del dit loch, ço es, per forment, ordi, / adaç̧a, paniç, li, faves, naps, ferrages, alffalffes, erba de paniç, erba de adacça roja et per tots altres blats et splets, erbes et legums», exceptuando el aceite, el quinto de la paja, el luísmo, la fadiga, el tercio diezmo, el derecho de alcaldía, la hilaza, y el huerto del señor. De esta forma se transformó la aportación individual que afectaba a cada heredad por una renta monetaria global. Estos 60 sueldos se debían pagar fraccionados en tres partes, quedando exentos en caso de guerra, ya que esta situación les obligaría a abandonar el lugar y a dejar las tierras yermas. La contribución monetaria, por consiguiente, se antepone a las particiones, que sólo se mantienen en el aceite, en la paja y en el tercio diezmo.

Don Ramón Castellá actúó de forma similar con sus vasallos moros en la mitad que le pertenecía de Catadau. En ella la partición de frutos quedó sustituida en el regadío por un arrendamiento cuyo pago anual ascendía a 4.000 sueldos, a los que había que sumar 2.200 sueldos por otros conceptos; pero, igual que en Llombai, el señor mantuvo la partición del aceite y el tercio diezmo ${ }^{17}$.

A comienzos del siglo XV, las cartas pueblas registran un retroceso en la modernización de las rentas en metálico, introducidas unos años antes al intensificarse las rentas en especie procedentes de las particiones. Este interés por participar en una tributación en especie fue bastante generalizado, pues durante este siglo los señores no sólo las impusieron, sino que las endurecieron, exigiendo habitualmente la tercera o la cuarta parte de los frutos de la huerta y la octava del secano, frente a la «huitena o desena del segle XIII».

La rigidez sobre las particiones debió operar más sobre el papel que en la práctica, ya que en la documentación de 1401 -a la que nos vamos a referir-ciertamente se pasa de unas rentas en metálico a una contribución en especie, pero inmediatas concordias influyeron decisivamente en estas particiones, estipulándose que parte de ellas volviesen a tributar en metálico, pues el señor buscaba una mayor liquidez económica.

Los capítulos concertados entre don Aymerich de Centelles y los mudéjares del lugar de Catadau referentes a los derechos que correspondían al señor en el año 1401, probablemente, tuvieron por finalidad actualizar unos derechos afectados por la reciente adquisición señorial de una parte de Catadau, que era propiedad de don Alfonso Suárez, y poner de manifiesto la situación de los mudéjares, gravados de forma diferente y discriminatoria ${ }^{18}$.

17. AHN: Sección Osuna, Leg. 722-6/7, Carpeta 95/17. Leg. 584-1/14. Carpeta 72/8. Agradezco a la Dra. M ${ }^{2}$ Luisa Cabanes la transcripción de dicho documento.

18. AHN: Sección Osuna, Leg. 722-6/2, año 1401. FEBRER ROMAGUERA, Manuel Vicente: «Antecedentes y configuración de los consejos de viejos». Actas del V Simposio de Mudejarismo, Instituto de Estudios Turolenses, Teruel, 1991, pág. 164. 
El citado documento, una vez expuesta la situación legal de dominio, continúa haciendo referencia a la partición de frutos, consistente en una cuarta parte en el regadío y la octava en el secano, a excepción del olivo, el cual, independientemente de su localización, partía a la cuarta parte. Así mismo, sólo aquellos que cosecharan aceite y lino estaban obligados a entregar de partición un «terraç de quin de arrova» del aceite, y del lino «una garba del dit lli». Esta entrega anual de aceite significaba un doble gravamen para un producto básico, lo cual dañaba la ya precaria economía de los mudéjares.

La tasación era distinta en función de la calidad de las tierras y de su ubicación (huerta, rahal, montaña). Esta variedad de particiones queda reflejada en las cartas pueblas que don Aymerich de Centelles (hijo del anterior) establece con sus vasallos de los cuatro lugares del señorío a comienzos del siglo XV (Cuadro $n .{ }^{\circ}$ I).

En aras de una mayor clarificación, en cuanto a la diversidad de particiones, cabe señalar que don Aymerich de Centelles amplió sus posesiones en Catadau y Aledua mediante la compra a su sobrino Grisogol Centelles de la mitad restante de Catadau y de siete heredades en Aledua, imponiendo a sus nuevos enfiteutas unos gravámenes muy semejantes a los del resto de sus vasallos ${ }^{19}$.

A tenor de lo expuesto, debemos destacar que en el «Trellat de població de Alfarb» de 1474, copia de «un llibre antich», concertado entre doña Tota Centelles y sus vasallos mudéjares de Alfarb se exponen nuevamente sus particiones; por lo que contamos con nuevos elementos comparativos que nos permiten afirmar que las particiones de Llombai y Catadau eran menores que las de Alfarb y Aledua (Cuadro n. ${ }^{\circ}$ I). Predominaban en los primeros la partición de un cuarto en la huerta y un octavo en la montaña, según la calidad de las tierras, mientras que en Alfarb y Aledua conservaban casi en la totalidad de los productos cultivados la onerosa partición de la tercera parte en la huerta y en el rahal, con algunas excepciones como en la zona o partida de Escondella y «les algoleches del riu», donde se potenció su explotación con una partición, más benévola, de una cuarta parte. Recordemos que la partición más generalizada en este periodo en el Reino de Valencia era a 1/5, con muchas variantes ${ }^{20}$.

A las variantes ya expuestas, debemos añadir otras referentes al modo de percibir el señor esta partición, puesto que en algunos lugares la parte de la cosecha que se debía entregar estaba sujeta a ciertos requisitos. En Alfarb se imponía que el lino partiese en la huerta al cuarto, pero los moros lo tenían que entregar ya preparado para su utilización «picat, examençart, amerat»; y en la huerta del rahal la partición era al tercio pero estaba condicionada según lo entregasen «picat vell o acabat de fer».

\section{AHN: Sección Osuna, Leg. 1028.}

20. AHN: Sección Osuna, Leg. 587, Año 1474. Alfarb. »Trellat de Població de Alfarb» otorgado por Doña Tota Centelles. Hinojosa MonTAlvo, José: «Señorío y fiscalidad mudéjar en el Reino de Valencia». Actas de V Simposio Internacional de Mudejarismo. Instituto de Estudios Turolenses, Teruel, 1991, pág. 113. 
CUADRO N. ${ }^{\circ} \mathrm{I}$

Particiones (Siglo XV) ${ }^{21}$

\begin{tabular}{|c|c|c|c|c|}
\hline Productos & Llombai & Catadau & Alfarb & Aledua \\
\hline Lino & $1 / 4$ & $\begin{array}{l}\text { Regadio } 1 / 4 \\
\text { Secano } 1 / 8\end{array}$ & $\begin{array}{l}\text { Horta } 1 / 4 \\
\text { Rahal } 1 / 3\end{array}$ & $1 / 3$ \\
\hline Paja & $1 / 4$ & $\begin{array}{l}\text { Regadio } 1 / 4 \\
\text { Secano } 1 / 8\end{array}$ & 1/3 (por gracia del Señor) & $\begin{array}{l}\text { Según la parte donde } \\
\text { se cosecharán los trigos }\end{array}$ \\
\hline Trigo & & $\begin{array}{l}\text { Regadio } 1 / 4 \\
\text { Secano 1/8 }\end{array}$ & $\begin{array}{l}\text { Huerta 1/3 } \\
\text { Escondella y Algoleges } \\
\text { del Río 1/4 }\end{array}$ & $\begin{array}{l}\text { Huerta } 1 / 3 \\
\text { Escondella y Algoleges } \\
\text { del Río } 1 / 4 \\
\end{array}$ \\
\hline Dacsa & & $\begin{array}{l}\text { Regadio } 1 / 4 \\
\text { Secano } 1 / 8\end{array}$ & $\begin{array}{l}\text { Huerta } 1 / 3 \\
\text { Escondella y Algoleges } \\
\text { del Río } 1 / 4\end{array}$ & $\begin{array}{l}\text { Huerta } 1 / 3 \\
\text { Escondella y Algoleges } \\
\text { del Río } 1 / 4\end{array}$ \\
\hline Panis & & $\begin{array}{l}\text { Regadio } 1 / 4 \\
\text { Secano } 1 / 8\end{array}$ & $\begin{array}{l}\text { Huerta } 1 / 3 \\
\text { Escondella y Algoleges } \\
\text { del Río } 1 / 4\end{array}$ & $\begin{array}{l}\text { Huerta } 1 / 3 \\
\text { Escondella y Algoleges } \\
\text { del Río } 1 / 4 \\
\end{array}$ \\
\hline Cebada & & & Huerta $1 / 3$ & \\
\hline Arróz & & $\begin{array}{l}\text { Regadio } 1 / 4 \\
\text { Secano } 1 / 8 \\
\end{array}$ & & \\
\hline Aceite & $1 / 4$ & $1 / 4$ & Rahal y huerta $1 / 3$ & $1 / 3$ \\
\hline Legumbres & & & $\begin{array}{l}\text { Huerta } 1 / 3 \\
\text { Rahal } 1 / 4\end{array}$ & \\
\hline $\begin{array}{l}\text { Cebollas, } \\
\text { ajos y otras } \\
\text { hortalizas }\end{array}$ & $1 / 4$ & & $\begin{array}{l}\text { Huerta } 1 / 3 \\
\text { Rahal } 1 / 4\end{array}$ & $1 / 3$ \\
\hline Algarrobos & & $1 / 4$ & $1 / 3$ & $1 / 3$ \\
\hline Higueras & & & $\begin{array}{l}\text { Horta } 1 / 3 \\
\text { Rahal } 1 / 4 \\
\end{array}$ & Concordia \\
\hline Viñas & & & $\begin{array}{l}\text { Huerta } 1 / 3 \\
\text { Rahal } 1 / 4\end{array}$ & Concordia \\
\hline
\end{tabular}

El rahal se encontraba localizado en el término de Alfarb, y el hecho de que las particiones de los productos allí localizados fuesen mucho más exigentes nos remiten

21. AHN: Sección Osuna, Leg. 722-6/2, año 1401. Catadau. Leg. 1028 Leg. 587, año 1474 Alfarb. Llombai: «Partexen de los moros de Llombai en la horta al quart e la montanya a la huytena».

Catadau: «Partexen la montanya a la huitena».

Alfarb: La partición de la viña y lino sujeta a condiciones.

En el «Trellat de poblaçio de 1474 de Alfarbe», las mismas particiones que en 1444 (fecha aproximada). Aledua: «Partexen la orta de Escondella ab les algoleges del riu a la quarta part». 
a su origen. Según Josep Torró, la denominación de rahal se aplicaba a las unidades de explotación gestionadas directamente por el señor, por lo que no es de extrañar que estas tierras conservasen una partición mucho más onerosa, con alguna excepción, como por ejemplo las hortalizas. No está de más precisar que es muy arriesgado hablar de particiones onerosas, ya que, tal y como señala Ciscar Pallares refiriéndose a las particiones en la Valldigna, para hacer tal afirmación tendríamos que tener en cuenta qué cantidad de tierra estaba sujeta a partición y cuál era la partición de cada uno de los productos gravados ${ }^{22}$.

En los señoríos de los Borja en el siglo XIV ya hay una clara tendencia a conmutar las particiones por censos en dinero, conservando, excepcionalmente, sólo las particiones procedentes de los frutos de los árboles ${ }^{23}$. Y en la «Foia» y Baronía de Llombai, mantuvieron ese mismo criterio mediante sucesivas concordias, las cuales, a partir de los siglos XV-XVI, fueron modificando este ingreso en especie por una cantidad fija en metálico.

Las razones de estas concordias, cuya trascendencia es innegable, tendríamos que buscarlas, entre otras motivaciones, en las nuevas adquisiciones territoriales de los Borja que, obviamente, exigían el desembolso de grandes cantidades de dinero. Consciente la casa ducal de Gandía de la necesidad de mantener y, a ser posible, incrementar sus ingresos, esta polémica familia se vio en la necesidad de percibir rentas en metálico y de aumentar la población en sus dominios. En este contexto socio-económicio, las concordias eran concesiones encaminadas a actuar de reclamo entre un campesinado en busca de mejores ofertas.

Tras negociaciones y renegociaciones, las concordias fueron modificando las particiones, concretamente entre 1505 y 1514 , sobretodo las referentes a las viñas e higueras. En las cartas pueblas del siglo XV se recoge la partición vigente hasta ese momento: «Parteix la verema del rahal e dich al quart ab les condicions damunt dites»; pero al margen de dicho apartado aparece la modificación establecida en la concordia del siglo XVI: «Pagen per concordia XVI lliures XVI sous vinyes y figueres».

La dimensión e importancia de las tierras establecidas eran difíciles de determinar, lo cual, frecuentemente, disminuía el monto de las particiones y enmascaraba los ingresos señoriales, tanto en su cuantía como en su procedencia, por lo que, en esta

22. TORRó ABAD, Josep: La formació d'un espai feudal, Alcoi de 1245 a 1305, Diputació de Valencia, Valencia, 1992, pág. 27. Presumiblemente, también hizo la función de albergue de ganadería: «lo cual cabesol de res son del terme de Rahal».La documentación del señorío cita el rahal como un lugar determinado, sujeto a diferente partición, con alguna excepción, como por ejemplo la viña, cuya tributación se ajusta a un censo. Al rahal se le ubica en el Marquesado en el límite del término de Llombai «confina ab Rahal». CISCAR PALLARÉs, Eugenio: La Valldigna..., Op. cit., pág. 14.

23. ARV: Sección Real Audiencia. Leg. 698. Aún siendo tan importante esta contribución, no es ocioso recordar que la partición de frutos entre la población mudéjar del duque de Gandía no estaba generalizada; si nos remitimos, por poner un ejemplo, a Mossen Bartolomé Sebastien, el cual afirma que muchos lugares de moriscos estaban «exemptos» de partición de granos y frutos, y sólo pagaban ciertos censos en dinero. 
concordia, se insistía en incluir las plantaciones nuevas, a la vez que se prohibía realizar posteriores plantaciones sin licencia del señor ${ }^{24}$.

Las abundantes notas marginales que acompañan a muchos de los documentos analizados son de gran ayuda, ya que indican modificaciones en las formas de pago mediante concordias, así como la convivencia de las particiones con antiguos derechos. Por ejemplo, en la relación de las rentas de 1403 la hoja de morera tiene una partición de la cuarta parte, y un siglo más tarde, concretamente el año 1540, se sigue manteniendo: «paguen cascun any per lo dret de la fulla per concordia a beneplacit de sa senyoria sis lliures, once sous pagadors feta la seda con son obligats a partirla a la cuarta part com parteixen tots los altres fruits».

Como ejemplo significativo de estas concordias sucesivas a las que nos estamos refiriendo, cabe citar la siguiente nota inserta en las rentas de 1542 «per lo dret de lo palla son obligats de partirla ab lo senyor a la cuarta part de la orta y de la seca a la huytena, paga Llombai y Catadau cascun any a beneplasit de la senyoria dotze lliures detze sous pagadores apres de batre», haciendo alusiones similares en posteriores relaciones de rentas.

En algún periodo y en algún caso, las concordias parecían a simple vista poco ventajosas para el señor, pero la situación del momento así lo exigía, entre otros motivos porque con el paso del tiempo las rentas en especie iban perdiendo vigencia, bien por la simple omisión, amparándose en que era costumbre antigua, o porque las entregas estipuladas en los productos sujetos a partición no eran las adecuadas ni en volumen ni en calidad. Ante estas situaciones, las concordias iban adaptando las rentas a los nuevos contextos socioeconómicos, revitalizando y garantizando ciertos ingresos.

Además, progresivamente, las concordias y rebajas fueron igualando la cuantía de las particiones en los diversos lugares. Así, el análisis de la relación de las rentas de 1540-1543 nos permite comprobar que las particiones en el lugar de Alfarb, siempre más gravosas, se igualaron en el siglo XVI con las de Llombai y Catadau, es decir, al cuarto en huerta y octavo en secano y montaña, manteniéndose alguna excepción, por ejemplo en las uvas y los higos, que siguieron partiendo al tercio; y es de suponer que en Aledua se seguiría el mismo criterio ${ }^{25}$. Y, según el cabreve de 1581 , las particiones de finales de siglo se habían unificado en el marquesado a $1 / 4$ en el regadío y $1 / 8$ en el secano, con algunas excepciones que reflejan esta tendencia a rebajar las imposiciones, especialmente en los productos con expectativas comercializables como la vid, con una partición de 1/11 parte, y la morera, hasta 1/20 parte, siendo también más benévolas en las tierras de nueva roturación, como las lindantes con el río, cuya partición rondaba $1 / 6^{26}$.

Después de todo lo dicho y teniendo en cuenta que la renta más importante del señorío provenía de las particiones, es muy importante resaltar que la tributación no era

24. PASTOR ZAPATA, Jose Luis: Gandia en la baixa Edad Mitjana: La vila i el senyoriu dels Borja, Alfons el Vell, 1992 , págs. 27 y 216.

25. AHN: Sección Ostuna, Leg. 587/18, Concordia de 1505.

26. AHN: Sección. Osuna, Leg. 937/3, Alfarb, años 1540-42. 
la misma para las dos comunidades residentes en el lugar, puesto que las particiones no afectaban en la práctica a los cristianos del señorío. Entre los documentos analizados no hay referencias directas en las que se indique que los cristianos viejos estaban exentos de partir los productos agrarios con su señor. Sólo de forma aislada aparecen escuetas alusiones, como la que hace el colector a mediados del siglo XVI al denunciar que los cristianos viejos no estaban sujetos a partición «per costum», sin más explicación. Parece ser que esta actitud permisiva hacia la comunidad cristiana estaba bastante generalizada. A partir de la citada carta puebla de Carlet (1520), afirma Rafael Benítez que los cristianos viejos tenían condiciones más favorables; y Colas Latorre indica que en Aragón la explotación morisca estaba toda, o la mayor parte, sometida a detracción, mientras que la de los cristianos podía estar total o parcialmente exenta ${ }^{27}$.

\section{2.- Adehalas}

Las adehalas son «la entrega al titular del dominio directo, por parte del común o de cada enfitéuta, de volatería o determinadas viandas como miel, perniles o quesos». Esta aportación, se entregaba en fechas señaladas, normalmente en Navidad, en reconocimiento hacia el señor por su condición de vasallos ${ }^{28}$. En el marquesado de Llombai, las normas que debían regir para satisfacer el «present» fueron objeto de atención por parte de los señores en el siglo XVI. Según se indica en un documento de sumo interés, fechado en 1538 , se ordena «lo que las aljamas del marquesado tenían que dar al señor por navidad», y pese a este enunciado, la adehala o presente también atañía a los cristianos viejos.

Los productos que componían el presente, así como la cantidad y calidad del mismo en cada uno de los lugares que formaban el marquesado, eran los siguientes: $\mathrm{La}$ aljama ubicada en Llombai aportaba 25 gallinas al año, de las cuales dos eran destinadas al baile y 23 al procurador general o para «aquí lo marques mana», mientras que la universidad de cristianos viejos (de Llombai) cumplía con la imposición entregando una gallina por casa al año. La aljama de Alfarb estaba gravada con 14 gallinas anualmente, de las cuales dos eran para el baile y doce debían mandarse a Valencia, es de suponer que para el procurador general. Completaba el presente una arroba de miel o su valor en dinero, junto con una arroba de pasas y tres docenas de «margallons». El presente de la aljama de Catadau consistía en la entrega anual de 18 gallinas, dos para el baile y 16 para el procurador, y una arroba de miel. Sólo Aledua quedaba exenta de la forma tradicional de aportar el presente, pues ya en el siglo XV pagaba por concordia una cantidad fija en metálico que, en el momento del acuerdo al que nos estamos

27. BENITEZ SÁNCHEZ-BLANCO, Rafael: «Las cartas pueblas.....» Op. cit. En cuanto a la importancia de las particiones recordemos que Rafael Benítez califica la carta puebla de la vecina Carlet (1520) más ventajosa para los vasallos que para el señor; $\mathrm{y}$, en el marquesado, la larga pervivencia de unas particiones, que como veremos se fueron deteriorando, también nos induce a pensar lo mismo. COLAS LATORRE, Gregorio: «El regimen señorial.....», Op. cit., pág. 13-18.

28. Gil Olcina, Antonio: La propiedad señorial en tierras valencianas, Del Cenia al Segura, Valencia. 1979, pág. 37; GozÁlbez ESTEVE, Elia: Análisis de un señorío..., Tesis cit., pág. 253. 
refiriendo, ascendía a 50 sueldos anuales para toda la comunidad; mientras que en la parte de Aledua de nueva adquisición se satisfacía el «present» con un sueldo y seis dineros anuales por heredad.

Estas aportaciones por parte de las aljamas de productos tan heterogéneos como aves, miel, pasas, «margallons», y la entrega anual, por la comunidad de cristianos viejos, de una gallina por casa y año, no debieron ser observadas con rigor, tal y como se expone en el documento al que a continuación nos referimos. En su contenido encierra éste condiciones y obligaciones semejantes a las establecidas en años anteriores, por lo que, obviamente, su finalidad era la de recordar una obligación deteriorada por los años: «E fas memoria y en lo present que portaren en les festes de nadal MDXXXVIII los de Alfarb no portaren sino set parelles de gallines y una cantarella de mel molt negra y molt lega la cual mel ja no volem prendre...».

El fraude de los enfiteutas a las arcas señoriales, tanto en la cantidad como en la calidad de lo entregado en concepto del «present», indujo a una investigación por parte de los jurados y del baile, que interrogaron a los vasallos. Como resultado de esta pesquisa se llegó a la conclusión de que hubo fraude, tanto en el número de gallinas enviadas a Valencia como en la cantidad y calidad de la miel, por lo que a partir de ese momento fueron obligados los vasallos a abonar el presente ya indicado, incluyendo algunas recomendaciones, como las dirigidas a los vasallos de Catadau y Alfarb, a los que se les reclama que la miel tiene que ser «la millor ques trobara e si aquells no la tendran bona lo dit procurador general pot comprarla a sa voluntat e fer la paguar al adita aljama». Con estas normas se pretendió vigorizar una renta señorial asegurando la calidad de los productos. Para ello se invistió al procurador general con la autoridad suficiente para poder rechazar dicho presente en caso de ser defectuoso y obligar a los vasallos a comprarlo, a su costa, de buena calidad ${ }^{29}$.

Incidiendo más en el contenido y destino de las adehalas del señorío, debemos precisar que los perceptores de las mismas debieron ser los señores en los siglos XIIIXIV. Pero los duques de Gandía, poseedores de un extenso patrimonio, capaz por sí mismo de aportar suficientes viandas a sus despensas, no las precisaban, por lo que compartían estos productos con sus subordinados, baile, procurador y personas de su confianza como forma de acrecentar o compensar sus salarios ${ }^{30}$.

Analizadas las rentas del marquesado durante el siglo XVI, sólo se hace referencia al «present» en Aledua, en donde se indica que por concordia se pagaban dos libras, tres sueldos por la fiesta de Navidad, mientras que en Llombai, Alfarb y Catadau esta aportación en especie iba directamente a los representantes señoriales; por lo tanto, es lógico que se omitiese su aportación. Sirva como ejemplo de su continuidad y del destino de parte de ella, los cuatro sueldos que, según el alamín, se pagaron a un morisco

29. AHN: Sección. Osuna, Leg. 587/17, año 1538. Margallons en castellano. Margalló es la parte central comestible del palmito. AHN: Sección. Osuna, Leg. 1028 (Aledua).

30. AHN: Sección. Osuna, Leg. 587/32. En el arrendamiento del año 1530 referente al presente de Navidad, en el capitulo 15 se dice «que la mitad del dit present sia dets dits arrendador $o$ arrendadors el altra mitad del dit ilustre señor don Francisco de Borja». 
por trasladar a Valencia «el present de nadal» de los cristianos viejos (cuentas 1535 39), y la relación de rentas confeccionada a raíz de la expulsión de los moriscos en el año 1609 , en donde se recoge, de forma detallada, lo que cada pueblo pagaba, según queda reflejado en el siguiente cuadro ${ }^{31}$ :

CUADRO N. ${ }^{\circ} \mathrm{II}$

\begin{tabular}{|l|c|c|c|c|}
\hline & ALEDUA & LLOMBAI & CATADAU & ALFARB \\
\hline Gallinas & 42 & 16 & 12 & \\
\hline Miel & & 1 arroba & 1 arroba & \\
\hline Palmitos & & 2 docenas & 2 docenas & \\
\hline Pasas & & & 1 arroba & \\
\hline Dinero & 14 L. 2 S. & 6 L. 2 S. & 6 L. 11 S. 7D. & 2 L. 10 S. \\
\hline
\end{tabular}

A finales del siglo XVI el presente de Navidad se había ido transformando en una paga fija anual en metálico, sin que podamos concretar hasta qué punto se mantuvo esta tendencia, ya que, por ejemplo, en el arrendamiento de 1607 el señor se reserva su percepción por entero, sin especificar la forma en la que quería percibirlo ${ }^{32}$.

En lo referente a la entrega de productos alimenticios, cabe matizar que la fiscalidad sobre las gallinas se aplicaba por dos conceptos distintos: las que correspondían al derecho de adehala y las que estaban obligadas a vender al señor a precio de tasa (impuesto que más adelante comentaremos). Esta diferenciación queda reflejada en el arrendamiento de 1530, en los términos siguientes: «si voldran puixen pendre gallines de la tanda al preu que los vassalls de la dita Foia he baronia son tenguts e ha costumats vendreles a sa senyoria puix no sia del present de nadal salvo del loch de Catadau lo cual reste per als dits arrendadors» (cap. XVI) $)^{33}$.

\section{3.- Alcaldía}

Si nos atenemos a su origen, «el dret de alcaydia» es de los conceptuados como derechos de tipo musulmán. Historiadores como Gil Olcina, Pla Alberola o Gual Camarena, por poner algunos ejemplos, indican que este impuesto proviene, o mejor sustituye, el salario del «alcayde» del castillo, afectando según los lugares a casas o heredades. Apoyan esta hipótesis cartas pueblas medievales como la de Buñol, de 1254, en donde el pago al «alcayt» se efectúa con los mismos productos y cantidad que, años más tarde, se entregarán bajo el epígrafe de «alcaydia»: «E que paguen al alcayt

31. AHN: Sección. Osuna, Leg. 582/2, año 1539; Leg. 937/3, año 1540; Leg. 1027, año 1563, (Cuentas 1535-39), Leg. 1027. Hay que tener en cuenta el momento y la intencionalidad de esta relación, ya que posiblemente estuviesen exagerados los impuestos.

32. AHN: Sección Osuna, Leg. 587/32, arrendamiento de 1530; Leg. 1027, arrendamiento de I607. El presente no siempre entraba a formar parte de los arrendamientos y en alguna ocasión el señor sólo cedía la mitad del mismo.

33. AHN: Sección Osuna, Leg. 587/32, arrendamiento de 1530. 
de castello un almut de trigo, un almut de paniço e una mayna de lino de cada casa, cada anyo en su tiempo $»^{34} \mathrm{o}$ «que vosaltres siats tenguts de pagar la alcaidia del alcayt qui sera per nos e los nostres en Gest, ço es un almut de blat per heretat $i$ un almut per cafis de blat que cascun cullira axi gros com menut, e una maja de lli de cada feix que es lo feix trenta majes ${ }^{35}$. En los señoríos aragoneses y valencianos el lino y los cereales eran también los productos elegidos para abonar los salarios del «saig», el de los guardias de huerta y el del barbero; recordemos que en el valle de Perpuchent también se pagaba por guardinaje una garba de lino. Así mismo, en la zona de Aranda, según García Marco, el «alcayde» en el año 1315 recibía por sus servicios «un manojo de lino de cuarto: 24 manojos y un cahiz de ordio por persona a mesura de Ricla ${ }^{36}$.

Este tributo de tradición islámica, destinado en su momento al salario del «alcayde», el cual ejercía el control de la vida económica de las comunidades campesinas, permaneció vigente para los mudéjares de la «Foia» y baronía de Llombai, como lo demuestra su presencia en las cartas o concordias concertadas entre don Ramón Castellá y sus vasallos en el siglo XV. El señor se reserva el cobro de la alcaldía y lo separa de otros ingresos (1381). El impuesto suponía «una barçella de paniç« anual por heredad, pero don Ramón Castellá cambió el panizo por trigo: «per almuts de forment a ras per cascuna heretat». Mientras, en Catadau, este derecho de alcaldía había sido hasta este momento de 20 cahices de grano de maíz y «forment» conjuntamente, pero el mismo señor lo rebajó a 16 cahices de «forment», reteniendo «al dret de la dita alcydia oli, $\mathrm{li}$, dret de vendes a la dita alcaydia pertanyent, co es, sis diners per cascuna heretat ques vendra), consistiendo este último apartado en un impuesto en metálico ${ }^{37}$.

Unos años más tarde, en el 1401, don Aymerich de Centelles dispuso que en Catadau la alcaldía se aplicase universalmente a todos los mudéjares con heredades, manteniendo la aportación en «forment» y sumando a ella una aportación en metálico más elevada, pasando de 6 dineros a 6 sueldos siempre que el vasallo vendiera la totalidad de sus bienes: «huna fane (fanecada) de forment a rras. E sis ven alcuna heretat

34. Gual Camarena, Miguel: «Los mudéjares valencianos, aportaciones para su estudio». Saitabi, $n^{\circ} 7$, 1949, pág. 187, nota 73; del mismo: Las Cartas Pueblas del Reino de Valencia, Generalitat Valenciana, Valencia, 1989, pág. 265. AHN: Sección Osuna, Leg. 722-6/2. Año 1401.

35. GUINOT RODRiGUEZ, Enric: Cartes de poblament medievals valencianes. Generalitat Valenciana, Valencia, pág. 602.

36. No debemos confundir esta aportación de lino con «el dret de lli» o la hilaza, ya que cadá una de ellas es y responde a impuestos diferentes. Hinojosa MONTALVO, José: «Señorío y fiscalidad mudéjar en el Reino de Valencià, Actas de $V$ Simposio Internacional de Mudejarismo, Instituto de Estudios Turolenses, Teruel, 1991, pág. 121; GARCí MARCO, Francisco Javier: «Fiscalidad, feudalismo y señorío en el mudejarismo aragonés», Ibidem, pág. 58.

37. AHN: Sección Osuna, Leg. 584-1/14, carpeta 72/8 y Leg. 722-6/7, carpeta 95/ 17. Año 1381. BENiTEZ SÁNCHEZ-BLANCO, Rafael: «Benimámet, una baronía...». Op. cit., pág. 255. Estas incorporaciones de paga suplementarias se repetian en algunos lugares cercannos; por ejemplo en Benimámet las tierras «quintadas», o sea las que pagaban la quinta parte de la partición de frutos, debian también abonar el derecho de «alcaydio» consistente en un cahiz de grano por cahizada de superficie. 
ab casa sis sous per alcaydia ${ }^{38}$. La incorporación al derecho de alcaldía de seis sueldos procedentes de las ventas conjuntas de heredad y casa, es una situación poco usual, y puede estar en estrecha relación con el deseo señorial de que no se vendieran los bienes en su totalidad, a fin de frenar los abandonos de los vasallos del señorío. Otro apartado del mismo documento refuerza esta hipótesis, al aparecer este impuesto junto al luísmo y la fadiga en Catadau, recordando esos seis sueldos que estaban obligados a entregar por derecho de alcaldía, siempre que las circunstancias fuesen las ya indicadas.

Pese a no ser un caso excepcional, el pago de la alcaldía en la «Foia» y Baronía de Llombai tiene la singularidad de su aportación en metálico y en especie según los lugares, afectando generalmente de forma individualizada, por heredad, a los miembros de la comunidad musulmana. No obstante siempre hay alguna excepción, y en éste debemos resaltar el papel de la aljama de Catadau, la cual se compromete el año 1401 a pagar de forma conjunta peita y alcaldía por $101^{\prime} 5$ heredades, desentendiéndose de «les IIII heretats e mija que sobren al senyor si pot haver l.alcaydiu e lo cens de aquelles, quel haja, e sino l.aljama non sia tenguts pagar per aquelles».

Dentro de estas variantes constatamos que el pago en especie de esta carga fiscal se satisfacía de forma similar en los cuatro lugares en cuanto a la aportación de «forment», mientras que la aportación en aceite, lino y panizo, presentaba algunas variantes de unos lugares a otros. Por tanto según el lugar se pagaba de diferentes formas: En Llombai: »Pagua cascun moro de alcaydia per heretat una faneca de forment, ara ne culla o ara non culla, a rras çoes les XXXV eretats»; además, «paguen los moros de Aledua qui tenen terra en Lombay qui fon de cristians per dret de alcaydia una faneca de forment per heretat aixi com los altres moros». En Catadau: «Una faneca de forment a rras ara'n culla o non culla», una «garba de lli» por heredad, un "terraç», que es un «quint de arrova de oli» y si se vendía toda la heredad se debían pagar «sis sous de Alcaydia». En Alfarb: «Una barçella de forment e una barçella de panis a corrent» y si no se encontraba entre sus cultivos el «forment», debían pagar en compensación todo en panizo, mientras que en el caso del lino sólo los que cosecharan estabas sujetos a la entrega de «dos garbes de lli per eretat». Así mismo sólo los cosecheros de aceite debían dar «Tot moro qui cullira oli, es tengut de dar al senyor per dret de alcaydia un terrac d'oli, lo cual terraç deu eser quint de una arrova ». En Aledua: «Una barçella de forment a corrent y una barçella de panis a corrent», y los cosecheros una «garba de lli ${ }^{39}$, puntualizando, que las siete heredades que compró don Aymerichs de Centelles a su sobrino Grisogol Centelles, estaban sujetas a alcaldía «segons los altres del loch de Aledua paguen». El impuesto de alcaldía alcanzaba también a los moros de Aledua que tenían tierras compradas a cristianos en Llombai, ya que eran los vasallos musulmanes los que estaban gravados con este impuesto, independientemente de donde estuviesen ubicadas las heredades.

38. AHN: Sección Osuna, Leg. 722-6/2. Año 1401.

39. AHN: Sección. Osuna, Leg. 1028. HaMILTON, Earl. J.: El tesoro Americano y la Revolución de los precios de España, 1501-1650, Crítica, Barcelona, págs.. 192-196. Medidas de áridos: cuatro cuarterones = almud, cuatro almudes $=$ una barchilla . 
De las anteriores citas se desprende que la imposición podía recaer sólo sobre los vasallos que eran cosecheros del producto solicitado, y en caso de no serlo, también cabían varias posibilidades: quedar exentos, que lo pudiesen conmutar por otro, o tenerlo que entregar, aunque para ello tuviesen que comprarlo, lo cual significaba un desembolso adicional a su ya amplia fiscalidad.

Como otros tributos en especie, la alcaldía se fue transformando en una aportación en metálico. En la relación de las rentas de antes de la expulsión, la tributación del trigo y del panizo se contabilizaba en arrobas según el lugar, o en su equivalente en metálico, pero no figuran las del aceite y lino anteriormente indicadas, probablemente porque hubieron desaparecido a lo largo del siglo XVI (Cuadro $n^{0}$ III $)^{40}$.

\section{CUADRO No III}

Derecho de alcaldía (rentas antes de la expulsión) ${ }^{41}$

\begin{tabular}{|l|l|}
\hline Llombai & «Por el trigo de alcaydia solían ser 4 arrovas 9 barçellas a 8 libras que daban 38 libras» \\
\hline Catadau & «El trigo de alcaydia era 16 arrovas 10 barsellas a 8 libras - 134 libras.» \\
\hline Alfarb & $\begin{array}{l}\text { «El trigo de Alcaydia era } 9 \text { arrovas } 5 \text { barsellas a } 8 \text { libras, } 43 \text { libras.El panizo de Alcaydia } \\
\text { eran } 5 \text { arrovas } 2 \text { almuds a } 3 \text { libras }-15 \text { libras, } 5 \text { sueldos.» }\end{array}$ \\
\hline Aledua & $\begin{array}{l}\text { «Por el trigo de alcaydia } 3 \text { arrovas a } 8 \text { libras, } 24 \text { L. Panizo de alcaydia era } 2 \text { arrovas } \\
8 \text { barsellas a } 4 \text { L - } 8 \text { L. } 18 \text { s. } 111 / 2 \text { dineros» }\end{array}$ \\
\hline
\end{tabular}

\section{4.- Alfetrán o cabezaje («Dret de fatra»)}

La capitación vecinal procedente del «dret de fatra o fatras», »fatera o satera» o «alfatra o alfitra», como se le denomina indistintamente en este señorío, en un alarde de apelativos, afectaba sólo a los mudéjares, los cuales de forma individual debían entregar a su señor «cascun cap per dret de fatra un almut de panis a corrent», sin límites de edad ${ }^{42}$. La raíz de este tributo debemos buscarla en la aportación que se entregaba a las mezquitas para su mantenimiento, en estrecha relación con el sustento del alfaquí o «alfaquinatge». A este respecto la carta de poblamiento de Chelva (1370) define el impuesto y la esencia del mismo en los siguientes términos: «Item, que seades tenidos dar por al.fetrá hun almut de panizo arraso por cabeza de persona de los quales se

40. AHN: Sección Osuna, Leg 1027/71. En las relaciones de rentas de finales de siglo, como la de 1563, sólo se indica que se sigue abonando el panizo correspondiente al derecho de alcaydía. BENITEZ SÁNCHEZBlanCo, Rafael: «Las Cartas Pueblas del condado...». Op. cit. pág. 205. En Carlet (año 1520) se pagaba «per cada heretat una barsella de panis y aquell dret es anomenat alcaydia».

41. AHN: Sección Osuna, Leg. 1027/63 (Rentas de antes de la expulsión).

42. GOZÁlBEZ ESTEVE, Elia: «Mudejares, cristianos y moriscos en el marquesado de Llombai». Revista Historia Moderna, $\mathrm{n}^{\circ}$ 17, Alicante, 1998-99, pág. 205. ORTEGA, Pascual: «La fiscalidad mudéjar en Cataluña), Actas de V Simposio Internacional de Mudejarismo, Instituto de Estudios Turolenses, Teruel, 1991, pág. 177. Pascual Ortega señala que en Mora el impuesto obligaba a todos los sarracenos, mientras que en Miravent y Mirasanet sólo afectaba a los mayores de seis meses, precisando que la «alfetra» era satisfecha con una entrega fija de cereal consistente, indistintamente, en cebada o avena. 
han dados a las ditas mezquitas de los ditos barrios dos cafices a cada mezquita, e lo que sobrara sea de la dita señora». Así mismo podemos enlazarlo directamente con la capitación de índole religiosa que se entrega, aun hoy, en la fiesta del fin del ayuno, según lo prescribe la Risala. Su pago desde siempre era en especie y en alimentos comunes, los cuales solían ser elaborados con «trigo, cebada o centeno...», y cuando algún musulmán tenía a otros a su cargo también debía contribuir por ellos «el zakatal-fitr» ${ }^{43}$.

Después de la Reconquista, el «dret de fatra» pasó a formar parte de los derechos de los titulares del señorío, los cuales lo compartieron con las instituciones religiosas islámicas, como fue el caso anteriormente citado, o se lo reservaron íntegramente, manteniéndolo en muchos casos de forma discriminatoria y obsoleta, aun después de la conversión. Así ocurrió en la Valldigna, donde, no sólo se mantuvo este impuesto entre los moriscos, sino que además, se hizo extensivo a los cristianos viejos en un alarde de equiparación de impuestos y obviando su origen islámico, pero con la única diferencia de que para estos últimos la tributación era en metálico y por casa ${ }^{44}$.

Aunque no se puede confundir este gravamen con otros, sí es posible que una misma tributación tomara nombres diferentes, según la comunidad a que afectara. Así, en la carta puebla de Carlet de 1520 se precisa la universalidad de este impuesto entre los mudéjares (tanto hombres como mujeres y niños) y su aportación de un almud de panizo por persona al año, aludiendo a su denominación en los siguientes términos: «en vocable morich ha nom alfatara y en cristianech cabesatge $\rangle^{45}$.

En Llombai, en el último tercio del siglo XIV (1381), Ramón Castellá libera a sus vasallos del impuesto de «alfatra» por una conmutación en metálico y lo aglutina con otros impuestos, lo cual enmascara su esencia pero, afortunadamente, recoge el significado que se le daba en ese siglo: «vol dir pagar a dret de senyor un almud de panizo universalment per cascun cap», independientemente de la edad ${ }^{46}$.

En el marquesado de Llombai, el derecho de «fatras» continuó siendo satisfecho con «un almud de panis», al igual que en otros lugares del ámbito valenciano, sin que la documentación consultada indique una fecha señalada para su recaudación; lo cual nos deja en la duda de si se mantendría el fin del Ramadán para su percepción, o si ocurría como en Xest, donde simplemente se ajustaban al calendario agrícola, esperando el momento de la cosecha para recoger el derecho en los siguientes términos: «Item siach

43. GUINOT RODRIGUEZ, Enric: Cartes de poblament medievals valencianes, Generalitat Valenciana, Valencia, 1991, N. ${ }^{\circ} 290$, Xelva (pág. 593-598). Compendio de derecho islámico. Risala-fi-l-Figh. Ibnabi Zayd Al-Qayrawani. (Ed. Jesús RIOSALIDO), Editorial Trotta, Valladolid, 1993, pág. 96-98.

44. Ciscar PAllarés, Eugenio: La Valldigna... Op. cit. En la Vaildigna este tributo era satisfecho con «un almut o celemin» de trigo por cada cabeza de morisco y 3 sueldos 9 dineros por casa de cristianos. pág. 203; GuAl CAMARENA, Miguel: «Mudejares Valencianos...», Op. cit., pág. 35-36, 92.

45. BeniteZ SÁNCHeZ-BLANCO, Rafael: «Las cartas pueblas...», Op. cit. capítulo 38, pág. 207.

46. AHN: Sección Osuna, Leg. 584-1/14, carpeta 72/8; Ramón Castellá, 1381. 
tenguts pagar cascun any a nos per dret de alfetra un almut de paniz per cascun moro o mora que sien de tres anys en ensus, lo cual dret paguets en lo temps del paniz $\rangle^{47}$.

Por lo general, se mantuvo la cantidad de un almud; pero el tipo de cereal, aunque solía ser panizo, variaba según los lugares, teniendo en cuenta el que se cosechaba en cada uno de ellos, y posiblemente también las preferencias del señor del lugar; por ejemplo, en Crevillente el cereal elegido era la cebada ${ }^{48}$.

La pervivencia de esta aportación en especie en el señorío queda patente en las relaciones de rentas del siglo XVI, en las cuales al citar la producción anual de panizo se menciona el entregado en concepto de «dret de fatras» con frases como estas: «ha provehit en lo ters de delme partisio de senyor al quart, alcaydia y fatra vint y dos cahisos dos barselles dos almuds...» o «panys mesura arras que se a collit en lo present any en lo dit loch de Catadau axi en lo ters delme com en la part del senyor compresa la satera». De igual modo, las rentas del marquesado antes de la expulsión recogen su contribución a la renta señorial, pero en esta ocasión tan especial se registra tanto el monto de la aportación en especie como su valor monetario; con la excepción de Aledua, donde, presumiblemente, había sido conmutado por un pago en metálico.

CUADRO N. ${ }^{\circ} \mathrm{IV}^{49}$

\begin{tabular}{|l|l|}
\hline Llombai & «El panizo de fatras eran 7 arrovas 6 barsellas a razón de 3 libras, 26 libras 4 sueldos» \\
\hline Catadau & $\begin{array}{l}\text { «El panizo de fatras era } 11 \text { arrovas } 3 \text { almudes a razón de } 3 \text { libras, } 33 \text { libras } 9 \mathrm{~s} . \\
41 / 2 \text { dineros.» }\end{array}$ \\
\hline Alfarbe & «El panizo de fatras era 6 arrovas 1 barsella a 3 libras, 12 libras 6 sueldos $21 / 2$ dineros.» \\
\hline Aledua & «Por panizo de fatras 8 libras» \\
\hline
\end{tabular}

\section{5.- Tercio diezmo}

Tarazona explica el fundamento jurídico del «Terç delme», basándose en la posesión que tenían los reyes de Aragón de todos los diezmos por concesión Papal y la donación de dos tercios del diezmo que hizo Jaime I a la Iglesia Valentina, reservándose un tercio para el erario real ${ }^{50}$. La progresiva transferencia del tercio diezmo a la nobleza fue una práctica frecuente en el ámbito valenciano. Una vez separada la primicia, el señor cobraba el tercio diezmo, que no siempre consistía en la tercera parte.

47. Guinot Rodríguez, Enric: Cartes de poblament... Op. cit., pág. 601 . El 10 de enero de 1371, Juan de Aragón, conde de las montañas de Prades y señor de Xest, otorga carta de poblamiento a los musulmanes que vivian en dicho lugar. BENitez SANCHEZ-BLANCO, Rafael: «Las Cartas Pueblas del condado...», Op. cit,. pág. 205. En Carlet ( 1520 ) pagaban el tributo por San Miguel.

48. Hinojosa Montalvo, José: «Renta feudal de los mudéjares Alicantinos». Señorio y Feudalismo en la Peninsula Ibérica, Institución «Fernando El Católico», Zaragoza, 1993, Tomo 1I, pág. 123.

49. AHN: Sección. Osuma, Leg. 1027.

50. TARAzOnA, Pere Jeroni: Institucions dels Furs y privilegis del Regne de Valencia eo sumari e repertori de aquells, Pedro de Gueto, Valencia 1580, (ed. facsimil, Paris-Valencia), pág. 418. 
Tal y como apunta Gil Olcina este representó, en algunos señoríos, hasta un $10 \%$ de los derechos dominicales, mientras que el diezmo entero podía subir hasta porcentajes entre $25 \%$ y $50 \%{ }^{51}$.

No debemos olvidar que el tercio diezmo era una renta vinculada directamente a la producción agraria y que, junto con las particiones, constituía la parte fundamental de las rentas, siendo su imposición muy generalizada en los señoríos valencianos, con escasas excepciones, como las de algunos lugares pertenecientes al duque de Gandía. Pero estas excepciones no son el caso de la «Foia» y baronía de Llombai, en donde el «terç delme» está ya presente en las primeras relaciones de rentas analizadas, constatando su presencia en los cuatro lugares que componían el señorío, con afirmaciones muy contundentes: «ha lo senyor tot ters de delme generalment de totes les coses $\rangle^{52}$.

Curiosamente, el sistema de recaudación del tercio diezmo en una población mixta, como la que aquí nos ocupa, es más universal que las particiones, ya que atañe a ambas comunidades. Los cristianos viejos, a mediados del siglo XVI, no pagaban partición «per costum», tal y como hemos indicado, pero sí tercio diezmo, lo cual induce al colector del año 1540 a incluir entre sus denuncias esta realidad en los siguientes términos: «per lo dret de panses de Llombai Catadau y Alledua que sols pagen lo ters delme y no part del senyor segons diu lo collector $10 \mathrm{~L}$. 5 sous» o «ha poçeit de forment en Llombai axi de ters delme dels cristians vells com ells no paguen part alguna perque així lo diu lo col-lector y tambe per lo ters delme dels moriscats» (Llombai) ${ }^{53}$.

La aportación en especie proveniente del tercio diezmo podía adoptar diferentes formas; por ejemplo, en el caso del vino se señala y se sugiere lo siguiente: «per lo ters delme del vi dels cristians vells de Llombai paguen al senyor de XXXXV canters de vi que cullen hun canter y seria molt millor que paguen en verema pera que lui torava al senyor de trenta carregues de verema a una carrega a poseit en lo present any quatre canters y mig de vi venut a raho de dos sous canter $\rangle^{54}$.

Al igual que en otros productos, tanto los cristianos como los mudéjares-moriscos estaban sujetos al tercio diezmo de la vid. Los cristianos viejos lo hacían en vino o «verema», según deseo del señor, y los mudéjares lo solían hacer con pasas, por ser el destino que mayoritariamente se le daba a la vid en esta comunidad. ya que eran muy apreciadas dentro de sus gustos culinarios, mientras que el consumo de vino, por motivos religiosos, era una de sus restricciones alimenticias; aunque hay que recono-

51. GlL OlCINA, Antonio: La propiedad señorial en tierras valencianas, Del Cenia al Segura, Valencia 1979, pág. 60.

52. AHN: Sección Osuna, Leg. 937, Rentas 1540-41; Leg. 1027/21. La casa de Gandía recibia tercio diezmo en Castellón de Rugat, Chella y Turis, por poner algunos ejemplos. GOZÁLBEZ EsTEVE, Elia: «Mudéjares y cristianos...» Op. cit., pág. 201.

53. AHN: Sección Osuna, Leg. 937. Rentas 1540-41. «Ha poseit dactza en Llombai en lo present any axi del ters delme dels cristians velis com del terç delme dels moriscats», «ha lo senyor lo ters delme del carnage axi dels cristians com de moros»y.

54. AHN: Sección Osuna, Leg. 1027-4. Renta de 1403. Leg. 1028. 
cer que los señores, interesadamente, potenciaron su bebida instalando tabernas en las comunidades mudéjares.

En ocasiones, lo que se recogía en especie en la renta anual era vendido a la aljama o al pueblo en general, detallándose en algunas relaciones de rentas del siglo XVI la compra por parte de los moriscos de los higos recogidos del «terç delme», así como el monto y precio de los cereales ${ }^{55}$.

La acusada irregularidad del tercio diezmo, al depender de la cuantía y de los precios de los productos, se pone de manifiesto en la documentación consultada, a la vez que evidencia la progresiva transformación de este impuesto de pago en especie a ingreso en metálico. Como renta en metálico, al no ser fija se devaluaba menos, pero el alza de los precios en Valencia a comienzos del XVI acentuó las necesidades monetarias de los señores, dejándose sentir esta realidad en el señorío, en algún producto y lugar: «per lo dret de les garrofes per los de Llombai com los lochs de Catadau, Alfarb y Aledua paguen en dines», o como «per lo dret de les panses per lo ters delme de Llombai Catadau y Aledua com Alfarb paga en dines a produit lo present any...» ${ }^{56}$.

El tercio diezmo concernía también a los ganados de ambas comunidades, afectando incluso a los capullos de los gusanos de seda, de cuya crianza y cuidado se obtenía la seda: «por el derecho del tercio diezmo de las onzas y vendas» ${ }^{57}$.

\section{2.- Prestaciones de dinero.}

En la Foia y Baronía de Llombai, la renta en metálico estaba formada por diferentes partidas, entre las cuales merecen especial atención: las peitas o magram, el luísmo y el morabatín, aparte de los impuestos que en algún momento tributaron en especie y que se transformaron en metálico, o viceversa. Recordemos, por ejemplo, que a finales del siglo XIV, por decisión de don Ramón Castellá (1381), acordada con sus vasallos, se cambió de renta en especie a renta en dinero, y que posteriores cartas pueblas y concordias fueron modificando nuevamente antiguos impuestos monetarios a especie, según el momento ${ }^{58}$.

\section{1.- Peita o magram}

La fiscalidad señorial era amplia, diversa y confusa; y la peita o magram siempre fueron los tributos que mejor se ajustaron a estos calificativos. La peita contribuía a las arcas señoriales anualmente, independientemente del resultado del año agrícola, lo

55. AHN: Sección Osuna, Leg. 1028. El precio de un cahíz de trigo era de 72 sueldos, el de maíz de 38 sueldos y el de panizo de 48 sueldos. Los higos recogidos el año 1559 , del tercio del diezmo, fueron vendidos a los moriscos.

56. AHN: Sección Osuna, Leg. 1028.

57. AHN: Sección Osuna, Leg. 1027, año 1563-64. El carnaje estaba sujeto a arriendo en el siglo XVI por espacio de un año, con dos pagas iguales por San Juan y Navidad, siendo los arrendatarios quienes percibian los perceptores del ingreso.

58. AHN: Sección Osuna, Leg. 584-1/14, carpeta 72/8 y Leg. 722-6/7 carpeta 95/17. Año 1381. Don Ramón Castellá, año 1381 . 
cual garantizaba, cuanto menos, unos determinados ingresos a la economía señorial. Sin embargo, un censo así concebido arrastraba el serio inconveniente de su indefensión ante procesos inflacionistas ${ }^{59}$.

Don Ramón Castellá, en su concordia de 1381, establece que cada heredad de Llombai pague 60 sueldos anuales repartidos en «tres tersos», en enero, abril y agosto $\mathrm{y}$ «apres seguent 7 et l'altre terça o paga per tot lo mes de deembre del prop dit any la donchs seguent et axi cascun any en per tots temps en los dits terminis sien pagats los dits sexanta sous per cascun heretat». La peita era gestionada por la aljama, pero a pesar de ser una tributación comunitaria el gravamen se repartía entre los miembros de la comunidad según sus posibilidades:

- Alfarb: «Pagua cascuna heretat cinch sous la mitat a Nadal el l'altra mitat a San Joan...». nadal».

- Llombai: «Paguen per eretat XXII sous la mitat a sen Joan e altra mitat a

- Catadau: «Pagua per heretat vint e cinch sous.... $\rangle^{60}$.

- Aledua: «Tres sous per cascuna casa». Y además «Item per cascuna heretat cinch carregues de lenya a rao de dos sous per carrega», «Item quatro gallines per heretat a rao III sous lo parell», «Item tres polls per cascuna heretat a rao de hun sou sis diners lo parelly.

Es complicado analizar este tributo en términos excesivamente generales, por lo que debemos considerar paralelamente otro impuesto, el «almagram» o «magram», emparentado con la peita en la medida en que afectaba a todos los cabezas de familia, pero, según Burns, diferente, ya que el magram, al menos en su origen, sólo gravaba la tierra en las comunidades de regantes. En primer lugar, debemos tener en cuenta que en este señorío ambos términos están presentes, ofreciendo una variedad difícilmente reducible a unas líneas básicas, por lo que citaremos el nombre que se aplica en cada caso concreto, siempre que lo permita la documentación disponible ${ }^{6 t}$. En algunos casos, la reiteración de los mismos hace que se simplifiquen las menciones en frases tan escuetas como «ha percebit», seguidas de la cantidad correspondiente, como única información registrada en las rentas. Y a esta ambigüedad debemos añadir que lo que en un momento fue un impuesto, con el tiempo pudo ser anulado, conmutado o anexionado a otro, perdiendo su identidad.

En la carta puebla de Catadau de 1401 todas las heredades mudéjares están sujetas a un censo en dinero, resultado de la conmutación de varios derechos, responsabilizán-

59. GIL OLCINA, Antonio: La propiedad señorial..., Op. cit., pág. 35, 36.

60. Don Aymerich de Centelles cobraba en concepto de peita de la parte de Catadau que había comprado a su sobrino Grisogol Centelles, 25 sueldos por heredad en dos pagas anuales, por San Juan de Junio y por Navidad. AHN: Sección. Osuna, Leg. 722/65, Leg.1028/ 80. Don Aymerichs de Centelles aceptó a la aljama de Catadau como garante de este impuesto, la cual se comprometió a pagar la peyta y alcaldía de 51 heredades y media. CisCAR Pallarés, Eugenio: La Valldigna... Op cil. pág. 191. Las tierras de huerta pagaban un censo global y otro fijo. El magram era abonado con tres pagas a lo largo del año.

61. BURnS, Robert I: Colonialisme Medieval, Editorial Tres i Quatre, Valencia, pág. 143. 
dose del mismo su aljama en los siguientes términos: «e per tots temps cascun any per los capitols de sus dits vint e cinch sous reals de valencia per cascuna heretat cascun any pagadors la meytat per tot juni e laltra meytat per tot lo mes de deembre cascun any e per tot temps», con una nota marginal aclaratoria diciendo que se trata de la peyta y que ésta afectaba por heredad.

Un poco más explícita es la relación de las rentas de 1403, en la cual se precisa, referente a Llombai, que los cristianos pagan peita y los mudéjares magram. A nadie escapa que las tierras de huerta suponían la parte esencial de la producción agrícola por lo que es de sumo interés conocer su fiscalidad. Pero esto entrañaba serias dificultades $y$, en nuestro caso, desconocemos si el apelativo de magram, impuesto que afectaba a los mudéjares, se aplicaba exclusivamente sobre las tierras de regantes, o si el empleo del término era tan sólo una reminiscencia de su antiguo significado ${ }^{62}$.

No debemos olvidar que los señores, generalmente, conservaron sobre sus vasallos mudéjares los impuestos islámicos, añadiendo paulatinamente otros pagos con denominaciones que les fueran familiares ${ }^{63}$. Con el paso del tiempo esta situación se hizo más confusa, ya que el distinto nombre de peita o magram no sólo concernía a diferentes comunidades, sino que además su origen era también diferente, señalando en alguna ocasión al magram como una peita ordinaria o peita de moros, y sin que podamos precisar en que momento el magram había perdido su significado de gravamen sobre el regadio.

Referente a si el pago de la peita era sólo por las tierras o afectaba conjuntamente a casas y tierras, en el siglo XV, en Llombai, se habla escuetamente de un impuesto sobre la «heretat». Pero en la relación de rentas del año 1534 se dice que este impuesto recaía sobre las casas y las tierras. gravando a los cristianos viejos con 4 sueldos y 6 dineros por casa y 1 sueldo y 4 dineros por hanegada de tierra, añadiendo «la cual peyta ni puja ni devalla», y manteniendo las tradicionales pagas de Junio y Navidad.

62. AHN: Sección Osuna, Leg. 722-6/2; Leg. 1027/4. Año 1403. Torró, Josep: La formaciò.., Op. cit. El magram es un impuesto que gravaba las huertas y cuyo origen se remonta al «delme coránico». Su presencia está justificada porque el regadio siempre presenta mayor dificultad a la hora de partir cosechas de poco volumen y además estas cosechas son muy diversificadas, por lo que -añade, el citado autor- no es de extrañar que hubiese un impuesto sobre ellas, posiblemente el magram, mientras que en el secano se podia prescindir de este tipo de matices, ya que las particiones presentaban menos dificultades. BURNS, Robert I: Colonialisme medieval.., Op. cit., pág. 143. Por su parte Burns considera que el magram o almagram estaba emparentado con la peita, en cuanto afectaba a todas las cabezas de familia, pero que era diferente ya que sólo gravaba la tierra de las comunidades de regantes, precisando que también llegó a pensar que el magram era un sinónimo de la peita, pero que encontró las dos palabras por separado en la misma relación de rentas y rectificó su hipótesis.

63. FERRER Y MALLOL, $\mathrm{M}^{a}$ Teresa: Les aljames sarraines per la Governació d'Oriola en el segle XIV. C.S.l.C., Institució Milà i Fontanals, Barcelona, 1988 pág. 123-130. La peita era la denominación cristiana de la alfarda, el impuesto comunitario más importante que consistía en una cantidad fija anual que cada comunidad musulmana repartia entre sus miembros. 
Por otro lado, los moriscos debían abonar «per el magram o peyta» por casas y tierras una cantidad global que ascendía a 38 libras y 10 sueldos al año ${ }^{64}$.

En principio, parece ser que la peita atañía a todos los residentes en el señorío, aunque debió haber excepciones, pues así lo dan a entender las quejas de la duquesa de Gandía sobre los pocos ingresos que había percibido por la peita de Catadau. Otras abstenciones o licencias aisladas de pagar peita, como la otorgada al alamín de Llombai, confirman estas irregularidades.

Por último, cabe hacer una breve referencia a la alfarda, impuesto que es citado en otros lugares al hablar del regadío y que en el señorío aparece en contadas ocasiones, siendo una de ellas en Llombai, en el año 1381, donde Don Ramón Castellá se reserva su captación. En esencia la alfarda era también un impuesto de origen musulmán satisfecho en metálico y que, según algunos historiadores, tenía que ver con la irrigación ${ }^{65}$.

Una vez más, la fiscalidad de tradición islámica es más compleja y difícil de catalogar, al margen de su rentabilidad. Posiblemente a los señores, en principio, les vino bien adaptar estos impuestos a la nueva situación de la comunidad vencida, pero ello no les garantizaba que esta fuese la fórmula más acertada entre todas las posibles.

\section{2.- Morabatín.}

El morabatín o monedaje se remonta al derecho del monarca en virtud de sus derechos de acuñación y para compensar las devaluaciones y garantizar una moneda sólida, aunque posteriormente se traspasó a los señores. Este impuesto señorial afectaba unánimemente a cristianos y a mudéjares, pero con una contribución monetaria diferente para cada comunidad. En algún periodo y lugar se expone que este impuesto quedaba condicionado a que las casas estuvieran habitadas en los siguientes términos: «cascun moro qui haura» (Alfarb) o «solo pagan morabatín las casas que están habitadas». Uno de los datos que nos indican la pronta despoblación de Aledua a finales del siglo XVI, es el hecho de que este lugar no contribuye a las rentas con el morabatín ${ }^{66}$.

Probablemente el derecho permaneció vigente hasta la expulsión de los moriscos, pues así se recoge en la relación de las rentas previas a 1609; aunque tampoco puede descartarse una interesada manipulación documental, pues dicha relación estaba encaminada a demostrar que la expulsión había perjudicado a la señoría, por lo que abultaron los ingresos anteriores a ella.

64. AHN: Sección Osuna, Leg. 586/10. Año 1534. COLAS LATORRE, Gregorio: «El régimen señorial en Aragón....». Op. cit. La palabra magram, en árabe, quiere decir, en términos generales, cosa pechada, principalmente referente a la tierra y casi siempre sobre la huerta. Muy acorde con esta definición, en el señorio, todo hace suponer que, en su origen, los vasallos mudéjares debieron satisfacer magram por la tierra de regadío.

65. FERRER y MALLOL, M: Teresa: Les aljames sarraines...., Op. cit., pág. 123-130. En términos generales, la alfarda era el impuesto comunitario más importante, consistente en una cantidad fija anual que cada comunidad musulmana repartía entre sus miembros. La peita era la denominación cristiana de la alfarda.

66. Ciscar Pallarés, Eugenio: La Valldigna... Op. cit., pág. 201. 
No quisiera seguir adelante sin antes mencionar la existencia de «xamesos» en el señorío y su participación a la renta feudal, ya que tanto las cartas pueblas de mediados del siglo XV como algunas de las relaciones de las rentas del XVI, citan puntualmente su contribución en metálico, consistente en tres sueldos y cuatro dineros; sin olvidar su relación con la carencia de tierras, en los siguientes términos: «los terratenientes que no tenen cases ni heretats que se dihuen gamesos paguen cascun any al senyor tres sous quatre diners». Se trataba de aparceros que trabajaban las tierras de otros a cambio de una parte de la cosecha y otras contribuciones menores, tal y como se recoge en ciertas alusiones a la temporalidad de su presencia, con expresiones como «si hia», a las que se añade el porqué de esta imposición «pagen los xamesos per no tenir cases ni terres»; al tiempo que la relacion de las rentas registra anualmente su ausencia o presencia y la oscilación de su aportación. En el señorío, los «xamesos» pagaban también un servicio sustitutorio en concepto de azofra, consistente en hilar para el señor anualmente cierta cantidad ${ }^{67}$.

En otros lugares, la aportación de los «xamesos» podía ser solo en especie; por ejemplo, en Xest, donde su carta puebla, otorgada a los musulmanes en 1371, también señala su carencia de propiedades y su participación impositiva en los siguientes terminos: «Item siats tenguts donar a nos e als nostres en lo mes de gener, axi aquell que te heretat com aquell que es examenç una gallina.... $\rangle^{68}$.

\section{3.- Luísmo}

El luísmo era la cantidad en metálico que se abonaba al señor en todas las ventas, permutas y trueques, mientras que la fadiga o derecho de retracto daba preferencia al señor en las compraventas, obligando al enfiteuta a dar aviso al señor 30 días antes de realizar cualquier enajenación, para que el dueño directo, si lo deseaba, pudiese adquirir el dominio útil. Según expone Antonio Gil Olcina, el luísmo y la fadiga están cuidadosamente regulados en los fueros del Reino de Valencia, y su denominación de luísmo (luisme o loisme términos utilizados de este señorío) acabó por prevalecer sobre la de quincuagésima y foriscapio, sinónimos que, empleados en sentido estricto, indican luísmos de una cuantía determinada, es decir 1/50 del valor pagado por el dominio útil en la quincuagésima y $1 / 3$ en el foriscapio ${ }^{69}$.

De forma un tanto obsesiva, a los señores de la «Foia» y baronía de Llombai les interesó desde sus inicios la percepción del luísmo; por ejemplo, en la carta que firma

67. AHN: Sección Osuna, Leg. 937. Año 1539; en el año 1542 pagan los xamesos tres sueldos y cuatro dineros.

68. Guinot Rodríguez, Enric: Cartes de poblament... Op. cit. El año 1371 «Joan de Aragó, conte de les montanyes de Prades y senyor de Xeçt, otorga carta de poblament als musulmans que hi vivien al dit lloc de Xest»?.

69. GlL OlcinA, Antonio: La propiedad señorial... Op cit. pág. 44. Quincuagésima para la mayoría de los romanistas tiene carácter de recompensa al concedente por prestar su consentimiento a la trasmisión de dominio útil, mientras que otros opinan que se trata más bien de una compensación al censualista por el riesgo de acoger a un enfiteuta desconocido. 
don Ramón Castellá con sus vasallos de Llombai el año 1381, tras algunas conmutaciones en dinero y aglutinaciones de tributos señala que se reserva el luísmo; y sólo unos años después, a comienzos del siglo XV, en los capítulos que convinieron don Aymerich de Centelles, señor de la «Foia» y aljama de Catadau, en el año 1401, se insiste en «que los dits moros del dit lloch de Catadau sien tenguts de pagar loysme cinch sous per lliura», es decir, un cuarto del valor de lo vendido, sin determinar quién debía pagar el derecho, si el comprador o el vendedor ${ }^{70}$.

Unos años más tarde, don Aymerich de Centelles (hijo del anterior) acuerda con sus vasallos de Catadau los luísmos a los que quedaban sujetos, manteniendo esa misma imprecisión respecto a quién debía pagarlos: «a lo senyor loysmes a fadigues paguas loisme de les cases e de la horta lo quart e lo de la muntanya a la huitena pero sis vendra tota la heretat la quarta pat del preu, e sis sous de alcaydia». No obstante, en esta anotación el luísmo prescrito es diverso en función de la calidad y ubicación de lo enajenado, bien sean casas o tierras, matizando si se trataba de tierras de la huerta o de la montaña, quedando además en evidencia el deseo del señor de retener a sus enfiteutas, cuyas ventas totales de sus bienes implicaba abandono del lugar y ser reemplazado por otro. Este cambio se le imponía al señor, por lo que en contrapartida exigía una compensación económica en concepto de alcaldía en Catadau, cuyo origen no desvela la documentación.

Para hacer una valoración aproximada de lo que representó el luísmo en este señorío debemos recordar que el luísmo establecido por el fuero tercero de la rúbrica «de feudis» es de 1/10 en los casos de venta y permuta, y 1/20 en el de hipoteca, el cual resulta muy superior al $2 \%$ prescrito por el derecho romano. El luísmo que se impuso a los vasallos de Catadau sobrepasó estas leyes y normativas, elevando su cuantía hasta un cuarto si se vendía la casa o la huerta, un octavo las tierras de la montaña, y un cuarto si la venta era conjunta de casas y tierras, a lo que debían sumarse seis sueldos de alcaldía, o tres si se vendía la heredad sin casa ${ }^{71}$.

Respecto a la cuantía del luísmo que debían pagar los enfiteutas en los restantes lugares del señorío, en el siglo $\mathrm{XV}$, es la siguiente: En Llombai, la cuarta parte del valor de lo vendido, tanto si vendían la casa y la huerta por separado, como si la venta era conjunta, sin especificar la calidad de la tierra, y la octava parte si las tierras están emplazadas en la montaña; en Aledua, las treinta heredades que la formaban debían pagar: «ha lo senyor loysmes e fadiges ço es la quinta part del preu», tanto las 30 heredades ya existentes, como las siete que se anexionaron mediante la compra que hizo don Aymerich de Centelles a su sobrino Grisogol Centelles, dando normas igualatorias

70. AHN Sección Osuna. Leg.7 22-6/7, carpeta 95/17; GoZÁLbEZ EsTEVE, Elia: «En torno a la percepción del Luísmo: El ejemplo del Marquesado de Llombaì, VII Assamblea d'Historia de la Ribera, 1998, AHN: Sección. Osuna, Leg. 722/6/2. Año 1401.

71. Grl Olcina, Antonio: La propiedad señorial..., Op. cit., pág. 45. 
a estos nuevos vasallos: «ha lo senyor loysmes, fadiges, herencies cofres e altres servituts segons he en altra part mia, com la poblaçio sia tota una» ${ }^{72}$.

A la luz de los datos que venimos y vamos a seguir comentando, comprobamos que el luísmo de un quinto en Aledua fue un caso aislado en esta baronía, donde no se volvió a repetir. Además se dio la circunstancia de que esta valoración abarcaba cualquier tipo de bien enajenado, no siguiendo el criterio diferenciador mantenido en Catadau, Alfarb y Llombai durante el siglo XV.

Numerosas referencias nos permiten afirmar que fue en Alfarb donde el luísmo fue más exigente, ya que supuso la tercera parte del precio establecido cuando la venta era conjunta, la cuarta parte si las tierras se encontraban en el rahal, y la octava parte si las tierras estaban en la montaña ${ }^{73}$. Lo primero que llama la atención de este luísmo es su elevada cuantía, al estilo de los foriscapios catalanes, constituyendo un hecho poco documentado, ya que sólo de forma aislada existen referencias a luísmos de un tercio, como el localizado por Pla Alberola en el marquesado de Guadalest ${ }^{74}$.

En la «Foia» y baronía de Llombai, el foriscapio ( $1 / 3$ del valor de la venta) lo encontramos en el lugar de Alfarb, lugar que también soportaba las particiones de frutos y azofras más exigentes, en relación con los otros lugares de la baronía. Esta coincidencia nos remite, como en otras ocasiones, a la diversidad de propietarios que en un principio tuvieron los diferentes lugares del señorío, los cuales según su criterio y por las circunstancias especificas de cada uno de ellos, sometieron a sus vasallos a distinta relación y tenencia de tierra. Este oneroso luísmo perdió su vigencia a comienzos del siglo XVI, tal y como lo recoge una nota al margen de dicho gravamen, la cual dice: «huy paguen de loisme la cetena part» ${ }^{75}$.

El perceptor del luísmo era el señor, pero al ser arrendado el señorío, los arrendatarios asumieron, en alguna ocasión, el cobro del impuesto, así como el derecho y la rentabilidad de obtener la licencia antes de realizar cualquier tipo de transacción. Obviamente, la implicación directa del arrendatario en el cobro de los lúismos representaba un mayor control de los mismos, pero a su vez le situaba en una posición privi-

72. AHN: Sección Osuna, Leg. 1028, Llombai, Catadau, Alfarb. Conviene matizar que en 1391 don Aymerich de Centelles logró la jurisdicción plena sobre la «Foia» y baronía de Llombai, a pesar de tener que compartir con otros señores la propiedad de estas tierras, situación que intentó subsanar por medio de sucesivas compras.

73. AHN: Sección Osuna, Leg. 1028. «Totes les cases, terres e heretats qués venen ha lo senyor lo loysme e fadigues ço es lo terç, e de la terra o possesions qués vendrá en rahal dich lo quart, e de la terra que's vendra de la montanya la huytena, empero si's vendra les cases e terres tot emplegat, ha de haver lo senyor lo terç del preù).

74. Pla Alberola, Primitivo: La población del marquesado de Guadalest en el siglo XVII, Instituto de Estudios Alicantinos, Alicante, 1983.

75. AHN: Sección Osuna, Leg. 1028. La nota carece de fecha, pero existen otras anotaciones al margen del mismo texto, fechadas en 1514 , con idénticas características. 
legiada para enmascarar determinados negocios y defraudar al señor en su patrimonio; y ésto fue lo que sucedió en el marquesado a mediados del siglo XVIII ${ }^{76}$.

Los luísmos y todas las cuestiones que les concernían aparecen sistemáticamente reflejados en sucesivos contratos y rentas, perfilando a lo largo del tiempo la complejidad de esta carga enfitéutica y dejando entrever el temor que suscitaba su posible pérdida al señor y a los arrendatarios, pues quedaban privados de un control que les era de gran utilidad para llevar a efecto la recaudación de sus rentas.

Entre los problemas que se plantearon, es de destacar la queja que expone el arrendatario a mediados del siglo XVI, referente a la pretendida exención de este gravamen por parte de los cristianos viejos. Esta situación le perjudicaba, por lo que el 9 de agosto de 1541 redactó un memorial dirigido a don Francisco de Borja, cuyo contenido encerraba una memoria de todas las dudas que se propusieron al señor sobre los derechos que debían pagar los vasallos cristianos y moros del marquesado ${ }^{77}$. En primer lugar, denuncia que los cristianos viejos se negaban a pagar luísmos, argumentando que nunca los habian pagado, lo cual no aclaraba si se trataba de un favor especial o simplemente que la fuerza de la costumbre se había impuesto sin que mediara ninguna negociación. La respuesta de don Francisco de Borja fue escurridiza e imprecisa, simplemente dijo que no había hallado ningún vestigio que determinase por qué los cristianos viejos no pagaban luísmos, por lo que suponía que debía tratarse de «gracia antigua por ser christianos o por grangería holgando los señores que los christianos vendiessen y comprassen los moros por el augmento de sus rentas» ${ }^{78}$. Y este proceder se repite en lugares cercanos como en Carlet (1520), donde a los cristianos se les exigía solamente la mitad del luísmo. Quizá esta medida no fuese tan arbitraria como parece a simple vista, ya que con ella los señores, velando por sus intereses, pretendían aumentar las ventas de los cristianos a los moriscos y engrosar las haciendas de esa minoría marginada sujeta a mayores censos y particiones ${ }^{79}$.

La segunda cuestión planteada en el memorial se centra íntegramente en la negativa de los moriscos a pagar cuando «baratan o truecan una heredad con otra o en caso de donación graciosa, que vuestra senyoria me hará merced de mandarme decir si lo deven pagar o no». En su contestación el señor confirma una vez más la obligación que tienen los moriscos de pagar luísmo siempre que no presenten justificantes de gracias y privilegios o se trate de dotes y testamentos, por ser consideradas estas transacciones

76. AHN: Sección Oszina, Leg 588/10, arrendamiento 1575. A este respecto, en el arrendamiento de 1575 se especifica textualmente: «es més pactat e concordat entre les dits parts que totes les licencies, axi pera comprar y vendre e los luysmes que durant lo temps del dit arendament se causaran sien del dit arrendator» (cap. XVII); GozÁLbEZ Esteve, Elia: «En torno a la percepción del Luísmo...». Op. cit.

77. AHN: Sección Osuna, Leg. 937/3. Llombai año 1540-41. Presentes la mayor parte de los jurados, Melchor Martínez arrendatario, Gabriel de Llanos bayle y Gutiérrez colector.

78. AHN: Sección Osuna, 154 I. Leg. 594/17, memorial de 1541.

79. Esta actitud estaba muy generalizada, según Burns y Gual Camarena, que documentan ampliamente la restricción de vender los mudéjares a los cristianos, en todo el reino de Valencia; BENíTEZ SANCHEZBLANCO, Rafael: «Cartas pueblas del condado...», Op. cit., pág. 150. 
privilegiadas y libres de toda carga, mientras que cuando se «baratan» unos bienes por otros dice textualmente: «Que no paguen más luysme de sola la demasia de la que vale la una heredad más que la otra». A pesar de que en el fuero de Valencia se establece que en dichos casos se entregue el luísmo entero, el duque de Gandía, marqués de Llombai, opta por que se aplique el luísmo sólo a la diferencia de valor entre ambas heredades, costumbre bastante arraigada entre los señores y destinada a paliar, en lo posible, la ausencia del pago de luísmos por trueques.

La cuantía del luísmo en el señorío se distanciaba considerablemente de esa décima parte regulada en los fueros valencianos; no obstante, a partir del siglo XVI, se unificó a la séptima parte del valor de lo vendido, prescindiendo de su ubicación y de otras circunstancias que habían sido, hasta entonces, determinantes a la hora de señalar el valor de los mismos ${ }^{80}$.

Otra cuestión que aflora en torno a los luísmos en el señorío es la ausencia de normativas con respecto a quién correspondía abonar el mismo. En los contratos enfitéuticos establecidos entre el señor y las aljamas en el siglo XV, muy explícitos en cuanto a la cantidad que se debía pagar de luísmo según la calidad del bien enajenado, no se dice nada sobre quién debía ser el que lo satisfaciera En el siglo XVI el criterio es cambiante de unos años a otros y aun hasta dentro de un mismo año, en que pagan el luísmo indistintamente el comprador o el vendedor ${ }^{81}$. Y en una referencia tardía del año 1756 don Francisco Benlloch, gobernador del marquesado, matiza esta cuestión: «Pero es de suponer que por costumbre paga hoy el laudemio el vendedor, aunque de derecho le pertenece al comprador por razón de investidura que del nuevo vasallo recive su señor, pero tambien lo paga en defecto de bienes del vendedor y si ni uno ni otro, se vende la alhaja que esta afecta y censida a este derecho, según así, lo ha practicado el actual Gobernador, cuyas providencias como primicias del nuevo señor marques ha ganado en juicio contradictorio» ${ }^{82}$.

80. GOZÁlbez Esteve, Elia: Análisis de un señorio....., tesis doctoral inédita, 1990. pág. 175-188. Sirva como ejemplo de lo dicho que los arrendatarios, en su relación de las rentas, recogen las ventas efectuadas cada año y lo que les corresponde por luísmo: en el año 1539 , por unas ventas de casas y tierras, recaudan la séptima parte del valor de lo vendido, y en 1540, 1541 y 1542 se insiste en que el luísmo es «de tres sous per ducat», manteniéndose esa séptima parte del valor de lo vendido en el período comprendido entre 1559 y 1564 . El Memorial redactado por los acreedores en 1611, antes de la expulsión, en su afán de resarcirse de las pérdidas ocasionadas, insisten en que « los luísmos se pagaban en el monte a la ochena parte y en el tahal al cuarto y de las casas y tierras que vendian juntas al tersio y esta tratando en la decena ahora»; AHN: Sección Osuna, Leg. 588/2, año 1539; Leg. 937/3, año 1540-43; Leg 1027/8, año 1559.

81. AHN: Sección Osuna, Leg 937/3, año 1559; Leg. 1027, años 1560-63. Por ejemplo, el año 1539 son los compradores quienes debían pagar el luísmo, en 1540-42 se dice «los moriscos paguen de lo que venen», y en 1559-1560 es nuevamente el comprador quien paga. Año 1564: «Recibio de la viuda Casboleta por un loismo de una fanegada de igueras que vendio a Cristóbal Arago por precio de 4 libras « o «Recibio de Abrahim Areli por un loismo de hun figueral de fruits que merco por 16 libras»; CISCAR PALLARÉs, Eugenio: La Valldigna... Op. cit ., pág. 101. Paga el comprador.

82. BeNLloch, Francisco: Marquesado de Llombay..., Op. cit., pág. 119; AHN: Sección Osuna, Leg. 1027. Año 1530. 
Enmarcados dentro de un estrato social inferior, sólo los mudéjares o moriscos pagaban luísmo en el señorío, y obviamente, este hecho, junto con fraudes, ocultaciones y continuas resistencias, hacían que este ingreso no fuese significativo; de ahí el interés tanto del señor como de los arrendatarios en avivar esta aportación a las arcas señoriales, sin olvidar el cobro de las licencias previas a estos trámites ${ }^{83}$.

CUADRO $\mathrm{N}^{\circ} \mathrm{V}^{84}$

\begin{tabular}{|c|c|c|c|}
\hline Ã்̃ & RENTA & LUÍSMO & $\%$ \\
\hline 1539 & 2200 L. 15 s. 8 d. & 7 L. $6 \mathrm{~s}$. & 0,31 \\
\hline 1540 & 2285 L. 2 s. 11 d. & 51 L. $5 \mathrm{~s}$. & 2,23 \\
\hline 1559 & 3042 L. 8 s. 10 d. & 57 L. $15 \mathrm{~s} .10 \mathrm{~d}$. & 1,87 \\
\hline 1561 & 2934 L. 4 s. 10 d. & 49 L. 15 s. 3 d. & 1,70 \\
\hline 1562 & 3278 L. 4 s. 10 d. & 20 L. 17 s. $1 \mathrm{~d}$. & 0,61 \\
\hline 1563 & 3912 L. $17 \mathrm{~s}$. & 59 L. 18 s. 3 d. & 1,53 \\
\hline 1564 & 5518 L. 2 s. 2 d. & 45 L. 5 s. 2 d. & 0,82 \\
\hline
\end{tabular}

\section{4.- Derecho de herencias}

El derecho a beneficiarse de los bienes de aquellos vasallos que no tuviesen herederos directos repercutía en provecho del rey, quien podía cederlo a la comunidad islámica, representada por sus aljamas. De igual forma, después de la Reconquista, tanto el rey como los señores receptores del derecho concedieron, en algunos casos, este privilegio a la comunidad mudéjar ${ }^{85}$. El señor con mero y mixto imperio, y aún si ostentaba sólo la jurisdicción alfonsina, tenía derecho a percibir los bienes del vasallo mudéjar que muriese sin herederos directos. Obviamente, esta definición es insuficiente y sólo nos sirve como mera introducción al tema, ya que entre otras cuestiones, no desvela la participación del señor en las herencias en estos casos; mientras que en el realengo contamos con magníficos ejemplos, en donde se enumeran minuciosamente todos los casos posibles y la participación en la herencia, tanto del rey como de los herederos estimados no directos, o sea, la esposa, hijas, hermanas, tías, etc., siendo consideradas siempre las mujeres y demás familiares femeninos después de los varones en la línea sucesoria.

Afortunadamente, la documentación analizada nos desvela parte de algunas de estas incógnitas, aportando matices importantes de un derecho islámico que pasó a ser real y más tarde señorial, con variantes según el lugar. En el siglo XIV (1381), en Llombai y en Catadau, los mudéjares podían dejar en herencia sus bienes a quienes quisieran, fuera o dentro del lugar, pero siempre que se cumpliesen ciertas condiciones.

83. AHN: Sección Osuna, Leg. 587/32. Año 1530.

84. AHN: Sección Osuna, Leg. 588/2, año 1539. Leg. 937/3, año 1540-43. Leg 1027/8, año 1559. Leg. 1027, años 1560-63.

85. GARCÍA ARANCON, Raquel: «Algunas precisiones sobre la fiscalidad de los mudéjares navarros». V Simposio Internacional de Mudejarismo, Teruel, 1991, pp. 246-247.. 
En caso de morir fuera de dichos lugares sin haber hecho testamento, los parientes que no vivían en ellos quedaban inhabilitados para percibir la herencia, no obstante podían heredar sus parientes que habitasen en Llombai y Catadau. Podía suceder que no tuviesen parientes en estos lugares, con lo cual la herencia recaía en cada una de las aljamas, siendo libres éstas «de donar et distribuir los dits bens, per amor de Deu, a coneguda de aquells» (Llombai) o «pertanguen et romanguen a la aljama del dit loch et que la dita aljama, vells et prohoms del dit loch pu-/ xen, els sia licit de donar et distribuir los dits bens per amor de Deu a coneguda de aquells» (Catadau).

Así mismo, si el mudéjar hacía testamento a favor de alguien ajeno a Llombai y Catadau, éste podía heredar con la condición de que se trasladase a vivir a dichos lugares: «et fer aquí residencia personal et / son cap major o de fer venda et alienació de les dites possessions, terres et cases a persona que stiga et habite et faça residencia personal en lo dit loch de Catadaur', y de igual forma en Lombai. En caso de no hacerlo, la aljama era la heredera y como tal podía disponer de los bienes libremente ${ }^{86}$.

En Catadau, tan sólo unos años después (1401), la normativa persiste en su severidad, pues no sólo impedía heredar si no se hacía testamento, sino que, aun testando, los mudéjares debían ceñirse a heredar en su lugar de residencia; y si éste estaba dividido entre distintos señores, situación que se había dado en Catadau, debían limitarse a heredar, forzosamente, sólo aquellos bienes que estuviesen emplazados en la parte del «raval» de su señor. A este respecto la concordia entre don Aymerich de Centelles y sus vasallos de Catadau, después de la adquisición que lo unifica, es muy elocuente: «Item com lo loch de Catadaur fos departit en temps passat ans que lo dit noble hagues comprat la part del dit mossen en Alfonso Suárez, e per dret nengun moro, ne per costum no pogues heretar nen//guna herencia sino en la sua part del seu raval, perque ara lo dit noble senyor vol, que la dita aljama puga heretar de la huna part al l'altra e l'altra de l'altra per guisa que les herencies sien en tot lo loch hunes pero que nengun estranger o barrani no puga heretar en lo dit loch». Con estas medidas los señores pretendían controlar al máximo a los vasallos asentados en sus territorios ${ }^{87}$. Estas citas ponen de manifiesto la restricción que pesaba sobre las herencias de los mudéjares, por lo que existía un rechazo unánime hacia la misma entre la comunidad islámica, que se opuso sistemáticamente hasta hacerla desaparecer.

El encargado de negociar los trámites testamentarios era el alcadí local, el cual debía presenciar el reparto de las herencias, aun en el caso de que fuese la aljama la beneficiaria; pero si en el lugar no había alcadí, el señor se comprometía a elegir uno (1381). Es de suponer que por esta gestión el alcadí percibiría una gratificación; al menos así sucedía en algunos lugares del ducado de Gandía ${ }^{88}$.

La pervivencia en el señorío del «dret de herencies» es difícil de determinar, ya que la información que nos llega es siempre demasiado escueta; por ejemplo, las cartas

86. AHN: Sección Ostuna, Leg 584/1-14, carpeta 72/8.

87. AHN: Sección Osuna, Leg. 1028, Catadau.

88. Hinoıosa MonTALVO, José: «La renta feudal....», Op. cit., pág. 124, «10 sueldos por derecho de alcadi». 
pueblas se limitan a registrar: «a lo senyor dret de herencies» 0 «lo senyor en los moros dret de herencies». Pero tal afirmación no nos permite conocer en qué casos se llevaba a la práctica, y mucho menos valorar con qué frecuencia y qué rentabilidad suponía, por ser uno de los ingresos más aleatorios y, además, presentarse junto a otros derechos percibidos en metálico ${ }^{89}$. En el marquesado, después de la conversión forzosa de los mudéjares, su corta permanencia, bien real o sólo sobre el papel, es un hecho a tener en cuenta; por ejemplo, en el arrendamiento de 1530 se expone en los siguientes términos: «y les herencies o dret de aquelles si empero les dites herencies los dits moriscats serán obligats a pagar e no en alta manera $\rangle^{90}$.

Por último, cabe insistir en que los señores de la «Foia» y Baronía de Llombai estaban interesados en participar en las herencias de sus vasallos, situación bastante frecuente en los señoríos valencianos, al igual que el rey en el realengo, aunque en ambos casos existían diferencias notables según los reinos ${ }^{91}$.

\section{5.- Otros impuestos}

Bajo el epígrafe de «dret», las cartas pueblas, concordias y relación de rentas aluden a derechos cuya enumeración es necesaria, pese a su escasa trascendencia. Se trata de pequeños impuestos abonados en dinero, cuyo origen, en muchos casos, viene de antiguos acuerdos. Entre estos derechos son de destacar: «el dret de palla, lenya, fulla, lli, alfas, vi, vinyes, figues, morera i treta».

Naturalmente, a lo largo de los siglos XV y XVI que estamos analizando, no todos mantuvieron siempre su vigencia, aunque su presencia en algún momento de este periodo les hace objeto de consideración en el conjunto de la fiscalidad del señorío. Por ejemplo, el «dret de lenya, en 1381, es uno de los tributos en especie que entraron a formar parte de un pago global anual en los siguientes términos: «per cent carreges de lenya posades en Valencia o doentes carregues de lenya posades en lo dit loch de Catadaur», y en 1401, también en Catadau, se cita este derecho señorial y la obligación de realizar el traslado a Valencia y a Catadau, conmutándolo por una cantidad en metálico. De igual forma, don Ramón Castellá aglutina el «dret de figues» a ese pago global al que nos estamos refíriendo, recordando que, antes de esta concordia, cada casa pagaba dos sueldos, nueve dineros , por este concepto,.

89. Monblanch y GonzÁlbez, Francisco de Paula: Historia de la Villa de Muro, Ayuntamiento de Muro, 1993. pág. 68-69. Una nota recoge el derecho de herencia en el año 1606 consistente en «4 sueldos y 10 dineros por derecho de vasallaje y herencias?

90. AHN: Sección Osuna, Leg. 587/3.

91. Pla Alberola, Primitivo: Conflictos jurisdiccionales, tesis doctoral inédita, 1985, pág. 630-633. El conde de Cocentaina, el año 1493, conmuta su derecho a heredar de sus vasallos mudéjares por un censo fijo anual de 18 dineros por casa; HINojosa MONTALvo, José: «La renta feudal.....», Op. cit. pág.128; GARCía ARANCÓN, Raquel: «Algunas precisiones sobre la fiscalidad de los mudéjares navarros», Actas de V Simposio Internacional de Mudejarismo, Instituto Estudios Turolenses. Teruel 1991. pág. 246. Mortuorio: «Como ingreso ordinario cabe incluir así mismo el derecho de mortuorio, que hacía pasar a manos del rey las heredades de los moros que morian $\sin$ hijos». 
Dentro de este conjunto de impuestos, «el dret de vinyes» en Catadau (1401) quedó regulado en una contribución flexible, pudiendo en el regadío subir el precio estipulado, pero no bajar, «pot pujar en Catadau e no devallar», y aceptando en el secano tanto que subiese como que bajase.

Otro derecho fue «el dret de palla», cuya aportación inicial en especie pasó a monetaria a partir de la concordia de 1505 , con una vigencia de seis años, que era el espacio de tiempo que abarcaba dicha concordia. Su cuota en Llombai y Catadau fue de doce libras anuales.

El derecho de la hoja de morera debió pervivir paralelamente a su partición, según se cita a comienzos del siglo XV, «per lo dret al senyor de fulla de morera 6 lliures 11 sous» (registrándose aparte las ganancias provinentes de la partición y del tercio diezmo de la misma). Así mismo, a mediados de siglo XVI, se precisa: «paguen cascun any per lo dret de la fulla per concordia a beneplasit de sa senyoría sis lliures onse sous pagadors feta la seda com son obligats a partirla a la cuarta part com partexen tots los altres fruits». La importancia de la seda en este periodo hizo que el cultivo de la hoja de morera fuese adquiriendo cada vez mayor relevancia, conservando el señor dicho derecho hasta la expulsión de los moriscos ${ }^{92}$.

En cuanto al lino, en las cartas pueblas de mediados del XV se insiste en que estaba sujeto a partición e hilaza, pero un siglo más tarde, concretamente en Alfarb, se había transformado mediante concordia en una cantidad fija en metálico por superficie cultivada ( 5 sueldos por hanegada). Es de suponer que en Llombai, Catadau y Aledua posteriores concordias producirían el mismo efecto ${ }^{93}$.

A partir del siglo XVI, el lino había sido desplazado, en parte por la hoja de morera, situación que queda patente en la renta de todo el marquesado de antes de la expulsión, en donde se dice que sólo se recaudaron 4 libras por este concepto.

El «dret de alffalffes» concernía a los lugares de Llombai, Catadau y Aledua en el siglo XVI, y posiblemente su origen procede de una anterior partición, ya que en la concordia de don Ramón Castellá (1381) con sus vasallos de Llombai lo incluye entre los productos sujetos a partición conmutados en ese momento por una paga en metálico. Este derecho, previo alfarrazamiento, afectaba por superficie cultivada: «pagen per alfarrazaments de alfalços quatro sous per fanecada, puja e devalla, munta present 53 sous» 0 «per lo dret de alfas pagen cuatre sueldos sis diners per fanecada cascun any son estat alfarrasat per lo colector y per los jurats han poseit segons alfarrasament 11 lliures 18 sous 7 diners pagadors a nadal $\rangle^{94}$. Su pago se cumplimentaba por Navidad, con escasas variaciones de un siglo a otro, tal y como queda reflejado en el cuadro siguiente:

92. AHN: Sección Osuna, Leg. 1027. Ibid. Leg. 937/3.

93. AHN: Sección Osuna, Leg. 588/2, año 1539. Leg. 937/3, año 1540-43. Leg 1027/8, año 1559. Leg. 1027, años 1560-63.

94. A.H.N Sección Ostuna, Leg 937/3. 


\section{CUADRO No $\mathrm{VI}^{95}$}

\begin{tabular}{|c|c|c|c|}
\hline AÑOS & LLOMBAI & CATADAU & ALEDUA \\
\hline 1403 & $8 \mathrm{~L} .3 \mathrm{~s} .8 \mathrm{~d}$. & $8 \mathrm{~L} .17 \mathrm{~s}$. & $5 \mathrm{~L} .4 \mathrm{~s}$. \\
\hline Mediados s.XV & & $10 \mathrm{~L} .12 \mathrm{~s} .3 \mathrm{~d}$. & $53 \mathrm{~s}$. \\
\hline 1539 & $10 \mathrm{~L} .9 \mathrm{~s} .6 \mathrm{~d}$. & $11 \mathrm{~L} .6 \mathrm{~s}$. & $5 \mathrm{~L} .2 \mathrm{~s}$. \\
\hline 1542 & $8 \mathrm{~L} .15 \mathrm{~s} .8 \mathrm{~d}$. & $10 \mathrm{~L} .8 \mathrm{~s}$. & $4 \mathrm{~L} .10 \mathrm{~s} .9 \mathrm{~d}$. \\
\hline 1559 & $13 \mathrm{~L} .5 \mathrm{~s} .3 \mathrm{~d}$. & $13 \mathrm{~L} .8 \mathrm{~s}$. & $5 \mathrm{~L} .2 \mathrm{~s}$. \\
\hline 1563 & $\begin{array}{c}16 \mathrm{~s} .2 \mathrm{~d} . \\
\text { más } 20 \mathrm{~L} .1 \mathrm{~s} . \\
\text { Alfas roig }\end{array}$ & $20 \mathrm{~L} .1 \mathrm{s.} 11 \mathrm{~d}$. & $6 \mathrm{~L} .14 \mathrm{~s} .4 \mathrm{~d}$. \\
\hline Rentas antes de la expulsión & $12 \mathrm{~L}$. & $10 \mathrm{~L}$. & $2 \mathrm{~L}$. \\
\hline
\end{tabular}

La saca de leña de Alfarb, a través del camino de Valencia, estaba sujeta a un «dret de treta». Citemos como ejemplo que, en 1540, se indica: «lo cami de Valencia per la obligasio que tenen los de Alfarb de pagar al señor dos dines per cascuna carrega de lenya que porten a Valencia», y en otro lugar «es arrendat a Masot Mahomet per cinch lliures pagadores a sent Juha y Nadal migerament». Este derecho de saca y arrendamiento se mantuvo vigente durante todo el siglo XVI, conservando la misma tasa de dos sueldos por carga $^{96}$.

\section{3.- Derechos jurisdiccionales}

Entre los ingresos en metálico, ${ }^{97}$ hay algunos provenientes de la participación de los señores en penas y composiciones en su condición de titulares de la jurisdicción. Estas cantidades no se especifican en las rentas, excepto lo percibido por guiages. Destacan generalmente por su poca importancia, pero su variabilidad hace que en algún año, como en 1542 , supongan el $8 \%$ de las rentas.

\section{4.- Monopolios}

Los derechos exclusivos, privativos y prohibitivos suponían en el señorío, al menos en el siglo XVI, una importante fuente de ingresos, tan solo superada por la participación en la producción agraria. Estos monopolios procedían de la pequeña manufactura rural de transformación, tanto de los productos agrarios como industriales y de los servicios a la comunidad.

Antes de entrar a hacer un sondeo individualizado de cada uno de los monopolios o regalías, debemos matizar que, cuando la gestión directa del señor se hizo inviable,

95. AHN:Sección Osuna, Leg. 588/2, año 1539. Leg. 937/3, año 1540-43. Leg 1.027/8, año 1559. Leg. 1027, años 1560-63.

96. AHN: Sección Osuna, Leg. 588/2-1540.

97. AHN: Sección Osuna, Leg. 1027/4, año 1403. Leg. 588/2. 
el señorío se arrendó, dotando a los arrendatarios del poder suficiente para exigir y sancionar, a través de los oficiales señoriales, cualquier reticencia o fraude concerniente a la fiscalidad. A su vez, las regalías se subarrendaron, por lo que sus ingresos dependían de las pujas o «postures» que alcanzaran en las subastas.

\section{1.- Monopolios sobre las industrias agrarias}

En primer lugar, hay que señalar la importancia de los molinos harineros de los cuatro lugares, llegando a ser una de las regalías más rentables para el titular de este señorío. Tanto en el siglo XV como en el siglo XVI las rentas recogen el arriendo del molino harinero de cada lugar por separado, pero a partir de mediados del XVI el arrendamiento se hace de forma global, anotándose la percepción de este sustancioso ingreso en la renta de Llombai. Citaremos como una simple referencia de lo dicho que el valor del arrendamiento de los molinos del marquesado en 1539 era de 125 libras, y en la renta de antes de la expulsión se cifra en 570 libras, representando un $44.78 \%$ de las regalías y un $10^{\prime} 33 \%$ de la renta. La relevancia de esta regalía obligaba a prestarle un cuidado especial de equipamiento y conservación, llegando a ser llamativa la lista de gastos que ocasionaba su mantenimiento ${ }^{98}$.

Respecto al molino de arroz, su aportación a las rentas era escasa, y sólo aisladas noticias nos informan de ingresos provenientes por servicios a forasteros en los siguientes términos: «ha hagut de moltures de forasters 5 su. $4 \mathrm{~d}$.» (año 1403), sin mayores precisiones, tan sólo añadiendo, en contadas ocasiones, algunos gastos ocasionados por su mantenimient «el moli de arros estava perdut y lo ha arreplegat el mestre Nadal Vilagut» $(1541)^{99}$.

La almazara, propiedad del señor, era arrendada en el XVI, y la documentación consultada da a entender que en su arriendo se incluía también el rendimiento del tercio diezmo y la partición de aceitunas convertidas en aceite, en los siguientes términos: «la almasera de fer l'oli ters delme y part del señor es arendada a Olbaydal Palletes vehi de Catadau per trenta arroves de oli»». Su rentabilidad fluctuaba considerablemente de unos añosa otros, sin que se especifique a qué era debido este comportamiento, aunque es posible que el origen de tal oscilación haya que buscarlo en la vecería del olivo ${ }^{i 00}$. En la práctica totalidad de los casos documentados, se observa que la piedra de la almazara, entendiendo que su arriendo se refiere al «pinyol» y la «revuelta», se podía arrendar por separado, aunque cabía la posibilidad de que el arrendatario fuese el mismo; y de hecho, así solía ser. El arriendo fraccionado de la almazara estaba en estrecha relación con las diferentes fases por las que pasa la elaboración del aceite, pudiendo ser arrendadas cada una de ellas por separado. No obstante, el señor se reservaba habitualmente

98. AHN: Sección Osuna, Leg. 937/3.

99. AHN: Sección Osuna, Leg. 1027/4, año 1403. Leg. 588/2.

100. AHN: Sección Osuna, Leg. 1027, año 1563. Por 600 arrobas, 600 libras. La almazara arrendada por 14 arrobas vendidas a razón de treinta sueldos veintiuna libra. La oscilación de las cosechas alternante era debido al tipo de aceitunas; por ejemplo la aceituna «mansanella» tiene ese comportamiento. 
«el orujo pinyol i remolta», y a veces también el derecho al último aceite, para lo cual exigía se le entregara el piñol «sense remoldre». Su precio se establecía de acuerdo con el aceite extraído, a razón de «6 dines per arrova de oli per tanda» ${ }^{10 !}$.

En una economía de subsistencia, las regalías que mayores ingresos proporcionaban en el señorio estaban estrechamente relacionadas con productos básicos alimenticios, tales como el trigo y aceite.

\section{2.- Monopolio sobre los productos industriales}

En la cartas pueblas de Llombai del siglo XV se recoge el arriendo del «tint» y el censo del molino de trapo «fa lo moli draper, cascun any cens ab fadiga, loisme e fadiga XX sous». Pero estos monopolios desaparecieron, sin que podamos precisar en qué momento, ya que la única información de que disponemos es una nota marginal inserta en dichas cartas pueblas, de forma tan escueta como «no ya tint»o «no ya moli draper $\rangle^{102}$.

Entre las regalías de esta índole, merece especial atención el molino de yeso de Alfarb, el cual era arrendado anualmente, caracterizándose por su puntual y sustanciosa aportación a las rentas, siempre en términos relativos.

Otro monopolio era el llamado «tierra de perayre», consistente en el arriendo de tierra cuya composición permite que se utilice en la construcción. Las tierras de estas características estaban sujetas a arriendo en Aledua y Alfarb a mediados del XV, $\sin$ que aparezca mención alguna a su forma de aprovechamiento, ni a si dicha extracción se hacía en cuevas, tal y como sucedía en otros lugares del entorno del señorío. Tal era el caso de Benimámet, en donde Rafael Sánchez Blanco cita, entre las regalías de dicho lugar, en este mismo siglo, la excavación de cuevas, precisando que por cada cueva que se abría en tierra de «pelayre» se debía pagar 20 libras al señor, durase lo que durase la extracción. En el marquesado, este monopolio se mantuvo en el siglo XVI exclusivamente en Aledua, mediante un pago fijo anual de 2 libras ${ }^{103}$.

En el siglo XV, don Aymerich de Centelles arrendó por separado en cada uno de los cuatro lugares de la «Foia» y Baronía de Llombai «l'almaxita», sin hacer ninguna aclaración sobre el contenido de la misma. Según Febrer Romaguera «l'amaxita» era un impuesto semejante al «dret de noces», que atañía a la mujer musulmana, la cual estaba obligada a pedir autorización para casarse y pagar por su cambio de estado. Magníficamente documentado, el citado autor indica que en algunos lugares como Chest, Beniopa, Almoines, Villalonga o Benaguacil, aparece el citado impuesto en diferentes anotaciones. La tributación individualizada era diferente si la novia se quedaba a residir en el señorío o si se iba a vivir fuera de él. El colector era el encargado de recoger el impuesto y depositarlo en la aljama, la cual, generalmente, se apropiaba

101. AHN: Sección Osuna, Leg. 937/3. Leg 1027/21.

102. AHN: Sección Osuna, Leg 1028. Cartas Pueblas.

103. AHN: Sección Osuna, Leg. 1027, año 1563; BENítez SÁNCHEZ-BLANCO, Rafael: «Benimámet: Una baronía», Op. cit., pág. 255. 
de estos ingresos, concertando con el señor un arriendo ${ }^{104}$. Este impuesto, considerado como regalía y sujeto a arrendamiento, no es muy frecuente, y cuando se cita se hace con expresiones tan vagas como: «Otrosi que ayades almasita por renta que me debes.... $\rangle^{105}$.

Esporádicamente, la relación de las rentas de Llombai de mediados del siglo XVI (1560-1564) contabilizan ingresos provinientes del molino de afilar herramientas «arrendado a Antonio Martí herrero por una libra 10 sueldos» o «el molino de amolar herramientas en todo el marquesado por 3 libras, 8 sueldos $\rangle^{106}$.

Dentro de este contexto, la documentación manejada recoge la presencia de unos hornos alfareros propiedad del marqués, llamados «olerías». Quisiera hacer hincapié en el nombre, ya que, curiosamente, aquí se ha perdido su designación como «olerías», mientras que en Latinoamérica se sigue llamando a dichos hornos alfareros con esta denominación. En las «olerías» el señor cobraba su derecho monopolístico por hornada, «per el dret de la casa de ollería» o «por el derecho del obrador de hollas an sé hecho cuatro jornadas a razón de 5 sueldos valen 1 libra». Se mantenía este derecho señorial aún en aquellos hornos de propiedad particular, tal y como se recoge en los siguientes casos: «por tres fornadas que Baltasar Camarell y su sobrino y Masare han hecho de hollas a razón de cinco sueldos por cada hornada que sé hase en los hornos o almadravas que tiene el señor marqués a tres sueldos por una jornada» y «por una fornada que Camarell hizo en un forno que a su costa hizo en su casa es por todo 28 sueldos $\rangle^{107}$.

\section{3.- Monopolios sobre los servicios de la comunidad rural}

Las rentas procedentes de la actividad mercantil y comercial estaban materializadas en la «Foia» y baronía de Llombai en las carnicerías, tabernas u hostal, tiendas, hornos... Lamentablemente, la documentación manejada no trasluce la complejidad de disposiciones referentes a las regalías del período que estamos tratando, limitándose a constatar su existencia y rentabilidad. La carnicería estaba sujeta, en el siglo XV, a un arriendo anual e individualizado, en cada uno de los cuatro lugares que formaban el señorío, mientras que en el siglo XVI, eran arrendadas globalmente: «les carneseries de tot lo marquezat», con una rentabilidad escasa. Ls distintas costumbres alimenticias, marcadas por la religión, quedan patentes en la necesidad que tenía Llombai, el único lugar con población mixta, de dos carnicerías, una para la comunidad de los cristianos

104. Febrer Romaguera, Manuel: «Colección de documentos. Regimen fiscal de las aljamas valencianas en arrendamientos de morerías», (en prensa).

105. Diccionario Maria Moliner, Gredos, Madrid, 1998, pp. 292. Masita (maxita): Cantidad retenida de las pagas a cuenta de la ropa suministrada a los soldados y clases. Cantidad pagada a los mismos para ropa.

106. AHN: Sección Osuna, Leg. 1027/21, años 1560-64.

107. AHN: Sección Osuma, Leg 588/2, año 1539. Leg 937/3, año 1542. Leg. 1027, año 1559. Leg 1027 , año 1562. 
viejos y otra para la de los moriscos, mientras que en Catadau, Alfarb y Aledua, de población musulmana, sólo tenían una carnicería ${ }^{108}$.

Desde antiguo fue habitual que anualmente se arrendara la caza, en términos como «la casa arrenda per...» o «per lo arrendament de la casera», concretando en el siglo $\mathrm{XV}$ que se trataba de la caza de perdices. Los arrendatarios solían ser moriscos, posiblemente por su habilidad en la crianza y caza de animales, sin descartar la necesidad de rentas complementarias. Afortunadamente, las relaciones de las rentas de ciertos periodos entran en mas detalles, precisando en el año 1539 que el arrendamiento de la caza de perdices se había otorgado a un morisco llamado Mahomet por valor de 5 pares y medio de perdices, no contabilizándose en la renta dichas perdices porque los marqueses tomaron parte de ellas cuando visitaron el marquesado y el resto se mandaron al procurador Joan García ${ }^{109}$.

Los vasallos estaban obligados a acudir al horno señorial para cocer el pan y en muy pocos casos se les dejaba libertad para poder cocer el pan en sus domicilios. Por su parte, el titular debía disponer de suficientes hornos en perfecto funcionamiento para cubrir las necesidades de la población. Atendiendo a esta obligación, se instaló un horno en cada pueblo del señorío, sujetos a arriendo. Pero el hecho de que en ese tiempo no aumentase su número, nos hace suponer que debieron quedar a todas luces insuficientes, siendo motivo de fricciones entre el señor y sus vasallos, tanto por la limitación de su número como por otras cuestiones referentes a su rentabilidad ${ }^{110}$.

Durante el siglo XV, el señorío tenía una tienda en cada pueblo en régimen de monopolio y sujetas a arrendamiento. Pero esta regalía también debió quedar insuficiente para una población que iba en aumento, por lo que en el año 1563 el señor amplía su número en Llombai, según se desprende de esta nota: «a arrendat las boticas de la plaça de Llombai», incrementando su aportación a las rentas a partir de ese momento.

También la taberna era gestionada a través de arrendamientos en los cuatro lugares. Su presencia no debe sorprendernos, aun tratándose de una comunidad mayoritariamente mudéjar, puesto que, generalmente, estaba protegida por los señores, hasta el

108. AHN: Sección Osuna, Leg. 1028. Cartas Pueblas.

GozÁlBez Esteve, Elia: Análisis del señorío, Op. cit., pág. 270, nota 199. Ingresos de las carnicerías en los siguientes años:

$\begin{array}{lll}\text { Leg. } 588 / 2 & 1539 & 55 \mathrm{~L} . \\ \text { Leg. } 937 / 3 & 1540 & 65 \mathrm{~L} . \\ \text { Leg. } 937 / 3 & 1542 & 100 \mathrm{~L} \text {. } \\ \text { Leg. } 1027 / 18 & 1560 & 90 \mathrm{~L} \text {. } \\ \text { Leg. } 1027 / 18 & 1561 & 70 \mathrm{~L} . \\ \text { Leg. } 1027 / 18 & 1563 & 90 \mathrm{~L} \text {. } \\ \text { Leg. } 1027 / 18 & 1564 & 120 \mathrm{~L} \text {. }\end{array}$

109. GOZÁlbeZ Esteve, Elia: «Cristianos, mudéjares....», Op. cit, pág. 195-218; AHN: Sección Osuna, Leg. 588/2, año 1539. Leg 937.

110. AHN: Sección Osuna, Leg. 1028. Cartas Pueblas. Leg. 1027/21, año 1563. Leg. 1028. Carta Puebla de Llombai; GozÁLBEZ ESTEVE, Elia: «Repoblación y repobladores», Actes de les I Jornades d'història local de Muro, Institut d'Història Almoroig, 2005, pág. 112-113. 
punto de prohibir a sus vasallos mudéjares beber fuera de la taberna de la morería. No podemos confundir la taberna con la tienda, ya que esta última también estaba arrendada durante este período ${ }^{111}$. En el siglo XVI no se registran ingresos procedentes del arriendo de las tabernas, pero se da la circunstancia de que en las rentas de Llombai de ese siglo se recoge el arriendo de un mesón u hostal, por lo que cabe la posibilidad de una fusión de servicios en este lugar.

El baño, tan arraigado en la cultura islámica, estaba ubicado en Llombai, centro neurálgico del señorío, y como tal, el que albergaba más servicios a la comunidad. No obstante, es probable que en los otros lugares también lo tuviesen en algún momento, y que fuesen propiedad de la comunidad musulmana, con lo cual no tenían porqué quedar reflejados en las rentas. Lamentablemente tenemos escasas noticias sobre el baño de Llombai; esporádicamente se le cita en las cartas pueblas del siglo XV como regalía señorial y sujeto a arriendo, pero una nota al margen recoge su desaparición, sin que podamos precisar la fecha exacta, ya que, simplemente se limita a exponer: «no ya bany que lo dona als christians per ferne casa». Dado que para la comunidad islámica el baño es considerado como un signo de identidad religioso-cultural muy importante, su eliminación por parte del señor y su entrega a los cristianos supone un trasfondo represivo, digno de tenerse en cuenta ${ }^{12}$.

Otras regalías sujetas a arriendos fueron las que afectaban al aprovechamiento de las cosechas silvestres, y aunque no es cuestión de entrar en demasiados detalles, interesa destacar la riqueza de la zona en miel, avalada por el constante arriendo anual de la «mel cucha» y de las colmenas en los siglos XV y XVI. Al tratar este tema, es conveniente hacer una pequeña matización referente a la «mel cucha o cuxa», la cual era miel cocida, o sea, aquella que por su consistencia y elaboración era más solicitada. Su arriendo se efectuaba por lugar y anualmente, pero a partir del siglo XVI se pasa a un arrendamiento global de todo el marquesado: «la mel cucha de tot lo marquesat». Respecto a las colmenas, según Burns, las abejas eran consideradas como bestiar «llur impost anava amb el nom de colmenes...». En el señorío la documentación analizada permite deducir que se trataba de un impuesto por colocar colmenas en el término, arrendado a razón de dos dineros por colmena al año, siendo de resaltar la afluencia de forasteros al señorío interesados en instalar allí sus colmenas ${ }^{113}$.

111. Hinojosa Montalvo, José: Los mudéjares. La voz del Islam en la España cristiana, , Documentos, serie Estudios Mudéjares. Teruel, 2002, Tomo II, pág. 301.

112. AHN: Sección Osuna, Leg. 1028; BURnS, Robert I.: Colonialisme medieval..., Op. cit., pág. 208.

113. Así se deduce de los siguientes ejemplos: «Cinco libras tres sueldos por ervaje de DCXVIII colmenas que han traido al término del marquesado forasteros a razón de dos dineros la colmena" (1539). «havido en el término quatrocientas LXI colmenas de ... a razón de II dineros por colmena III libras Vl dineros « (1559). «ha havido en el término 860 colmenas que a razón de dos dineros por colmena valen 7 libras 3 sueldos» (1562).«an erbasado en el termino colmenas moriscos de Buñol y de TorresTorres 672 colmenas a razón de 2 dineros 5L. 12 su.» (1563) Sección Osuna Leg. 588/2. Leg. 1027/18. Leg. 1027/21. 
La ganadería del marquesado destacaba entre las de la comarca de la Ribera Alta, representando una fuente de riqueza considerable, tanto por su capacidad de autoabastecimiento como por la venta del excedente, sin olvidar la aportación monetaria proveniente del paso de las ganaderías transhumantes y del estiércol generado utilizado como fertilizante ${ }^{114}$. Referente a la ganadería transhumante, en el señorío se arrienda: «el derecho de la asadura de los serranos que pasan por el término a Vicent Comptet per 2 lliures» o «el paso de los serranos que pasan por el término pagan de cada cavaja una res, arrendado a Azmet por 2 libras», o simplemente, «por el paso de los serranos». Por tanto, no es de extrañar que las rentas de la década de los sesenta del XVI se hiciesen eco de esta situación, ya que la zona era apta para la ganadería local, con la suficiente capacidad para poder albergar ganados foráneos, al menos en la época invernal.

La llegada al señorío de los ganados castellanos y aragoneses tenía lugar en los meses de octubre, noviembre y diciembre, abandonando estas tierras en primavera, hecho que justifica que el pago del arriendo del herbaje se hiciese en abril. La toponimia de la zona hace reiteradas referencias a estas actividades ganaderas, como la denominación del camino de «els assagadors» o «corrals», por poner un ejemplo. Pese a todo lo dicho, no se olvidaba la protección a la agricultura, imponiendo penas por los daños causados por los ganados: «que los erbasantes que erbasen y comiesen con sus ganados las tierras yermas que estuviesen arrendadas no paguen sino el daño que causasen fuera del bovalar y si fuera en el bovalar pagen la pena acostumbrada». La existencia de una importante cabaña lanar y el paso de la ganadería trashumante propiciaba que el dueño del lugar arrendara anualmente el «herbaje» del término en los cuatro lugares. No olvidemos que, según Burns, el herbaje era un impuesto muy importante introducido por Jaime I en el ámbito valenciano.

Otra actividad ganadera era la cría de los gusanos de seda, pero la información señorial analizada se centra más en la actividad artesanal del hilado y tejido de la seda que en la compleja infraestructura que requiere el cuidado de estos animales.

A grandes rasgos, cabe añadir que el señorío era arrendado y que el arrendador subarrendaba a su vez los monopolios, habitualmente a vecinos del mismo. Afortunadamente, en la relación de las rentas estos subarriendos son bastante precisos, llegándose a indicar el credo de los subarrendadores (cristianos viejos o moriscos a partir de 1522) y su oficio. El periodo de tiempo por el que se subarrendaban las regalías en el marquesado era de un año, y su importe se entregaba en dos pagas iguales, una por San Juan y otra por Navidad ${ }^{115}$.

La rentabilidad de las regalías era en general elevada, representando alrededor de un $24 \%$ de la renta, aunque para ello requerían continuos cuidados y reparaciones, Su buen funcionamiento ocasionaba importantes desembolsos que quedaban, generalmente, registrados en los gastos de mantenimiento del señorío, desvelando la docu-

114. Peris Albentosa, Tomás: Historia de la Ribera. De vespredes de les Germanies finsa la crisi del Antic Règim, Ribera Alta, 2001, vol. 1, pág. 87.

115. AHN: Sección Osuna, Leg. 1028 En Catadau sólo se arrienda la mitad de las regalías citadas y nada se dice de la otra mitad a la que pertenecían las 7 heredades compradas con posterioridad. 
mentación analizada un continuo interés por parte del señor en su conservación, hasta el punto de hacer algunos gastos económicos, como el préstamo de 20 libras, en 1540, a Jeroni Mandarani, subarrendador de las carnicerías, con la condición de «que les ha de tornar als dits termins»; esta actitud, aun siendo un simple préstamo, era muy poco frecuente entre la nobleza ${ }^{116}$.

\section{5.- Azofras}

Generalmente, se acepta el hecho, muchas veces comprobado, de que la fiscalidad de los mudéjares era distinta y discriminatoria. No obstante, una extensa bibliografía desigualmente documentada y con distintos planteamientos metodológicos ha incidido sobre el tema reiterativamente, y si bien es cierto que autores como Laparra, estudioso del ducado de Gandía, apuntan que quizá, en muchos casos, la historiografía ha exagerado las diferencias existentes entre estas dos comunidades, debemos tener en cuenta también que el citado autor centra su investigación primordialmente en un importante núcleo urbano, mientras que nosotros estamos hablando de una comunidad rural donde esas diferencias estaban lejos de ser imaginarias ${ }^{117}$. Por ejemplo, aunque nos sea difícil medir su intensidad, existía una corriente migratoria que iba de las tierras señoriales a las realengas, y a pesar de ser ésta una cuestión muy debatida, induce a pensar que la vida de los campesinos de señorío debió ser más dura que la de aquellos que vivían en el realengo. De lo contrario, difícilmente puede entenderse la prohibición a cambiar de residencia que pesaba sobre los vasallos mudéjares del señorío.

Si nos atenemos a la "Foia» y baronía de Llombai, las siguientes líneas ponen de manifiesto esta situación, tanto antes de pertenecer el señorío al ducado de Gandía como después, ya que a pesar de la bien ganada buena fama de solidaridad que gozaba el duque de Gandía con sus vasallos mudéjares, comprobamos que las distinciones de trato con respecto a los cristianos viejos se dejaron sentir, aun después de ser bautizados los mudéjares ${ }^{118}$.

Centrándonos en el tema de las azofras en este señorío, no está de más recordar que en el ámbito valenciano existían aspectos diferenciales entre estas dos comunidades, provenientes de una serie de derechos musulmanes, como los servicios personales y las prestaciones que fueron manipuladas y utilizadas por los señores después de la Conquista. Es el caso de las imposiciones que continuaron recayendo sobre los mudéjares del señorío bajo la denominación de «asofres». La documentación analizada nos permite conocer en profundidad esta renta, y si tenemos en cuenta que, según Pierre Guichard, hay un general desconocimiento sobre las azofras, la magnífica información

116. AHN: Sección Osuna, Leg. 937/3, año 1540.

117. GozÁlbez Esteve, Elia: Analisis de un señorio valenciano..., Tesis cit., pág. 203, 242.

118. HALPERIN DONGHI, Tulio: Un conflicto nacional: Moriscos y cristianos viejos en Valencia.,Institución Alfonso El Magnánimo, Valencia, 1980, pág. 58-59; LAPARRA LóPEZ, Santiago: «La Fiscalidad mudéjar en el ducado de Gandía: El Ducat de foc». Op. cit., pág. 265-267; GoZÁlBEZ ESTEVE, Elia: «Cristianos, mudéjares...», Op. cit., pág. 95-218. 
que nos brinda este señorío es de gran utilidad para poder ahondar en esta imposición vejatoria en sus muy variadas manifestaciones ${ }^{119}$.

Referente al término «sofra», Burns rechaza su vinculación con el «servei» (servicium), susceptible de diversos significados, y propugna su identificación con la «azofra», palabra que proviene del arabe as-sukhra, precisando que las formas latinas oscilaban entre çofra, sofra y zofra, sin dudar de su origen romano. Pero analizar el origen del concepto de la azofra está fuera de la intencionalidad del presente trabajo, por lo que tan solo citaremos que éste ha dado lugar a una polémica suscitada entre Guichard y Burns. A grandes rasgos, Guichard acusa a Burns de un esfuerzo continuista por hacer entrar el feudalismo en la Valencia islámica, y Burns argumenta que la utilización de términos que describen un momento determinado es válida para otros semejantes.

Afirma Guichard que la azofra no era frecuente en la época islámica, aunque llega a reconocer que podría tratarse de una carga estatal, mientras que para los cristianos era una carga señorial, explicando que las autoridades musulmanas (Alcadí y Cadí) ya obligaban a los habitantes a llevar a los castillos las rentas en especie, así como a realizar ciertos trabajos de interés público tales como reparación de murallas, trabajos de restauración de puentes, caminos y faenas agrícolas. Añade que con la conquista cristiana, y en el curso del siglo XIII, la situación y organización de los musulmanes quedaron, en el reino de Valencia, completamente modificadas por su integración en un cuadro socioeconómico fundamentalmente nuevo, que se puede definir como señorial y feudal.

Por su parte, Burns asegura que la azofra es de origen islámico y que, aunque su significación primera fue la de mantener las murallas y castillos, también se puede ampliar a un "servitutem castrorum» consistente en transportar al castillo principalmente agua y leña, mientras que la entrega de productos agrícolas, los jornales o trabajos (de un número determinado de días), quedarían un tanto diferenciados de la azofra $^{120}$.

Además, algunos autores creen que las prestaciones o servicios personales de los mudéjares valencianos no existían después del XIII, originándose en el XV a raíz de una penosa opresión. No obstante, Burns estima que se trata de una opinión demasiado generalizada, por lo que puntualiza que el trabajo físico prestado al señor no tenía gran importancia durante el siglo XIII, y quizá ésta sea la razón por lo que no se registrara; pero ciertamente existía, y no siempre podía sustituirse por conmutaciones monetarias $^{121}$.

119. GuICHARD, Pierre: «Le probleme de la sofra dans le royanne de Valence au XXIII siecle», Madrid, 1979; GOZÁlBEZ ESTEVE, Elia: Análisis de un señorio valenciano... Tesis cit., pág. 204-229.

120. GuiChARD, Pierre: «Le probleme de la sofra...», Op. cit. BuRns, Robert I.: Colonialisme medieval..., Op. cit.; BuRns, Robert I.: Moros cristians i jueus en el regne croat de valencia, Ed. Tres i Quatre, Valencia, 1987, pág. 67-71.

121. GozÁlbez Esteve, Elia: «Las azofras en el marquesado de Llombai», Señorío y feudalismo en la Peninsula Ibérica XII-XIX, Institución Fernando El Católico, Diputación de Zaragoza, 1993. 
Sea cual fuera su origen, las azofras constituyen un rasgo diferenciador entre ambas comunidades. En las concordias que don Ramón Castellá emite en 1381 para sus vasallos mudéjares de Llombai y Catadau, se citan y precisan en qué consistían algunas azofras, así como su antigüedad y la conmutación en metálico de esta carga. $Y$ de igual forma, la documentación posterior del señorío, como la concordia de 1401 entre don Aymerich de Centelles y la aljama de Catadau, y las cartas pueblas del siglo XV referentes a Llombai, Catadau, Alfarb y Aledua realizadas por su hijo, el también Aymerich de Centelles, insisten en su pervivencia; y su magnífico contenido nos da la oportunidad de penetrar en su estructura. Bajo el epígrafe de azofras, la documentación del señorío nos permite distinguir los siguientes apartados:

\section{1.- Mantenimiento de fortificaciones y avituallamiento de leña}

La identificación primaria de là azofra se manifiesta como la obligación de mantener las fortificaciones ya existentes o la creación de nuevas, así como abastecer de agua y leña al castillo. Su revitalización, tal y como lo expone Burns, podía obedecer a que esta obligación se hubiera perdonado (se refiere a las construcciones defensivas) y que se impusieran nuevamente, de forma general, por castigo después de las primeras revueltas, según lo interpreta Guichard, o que se tratase simplemente de una precaución militar.

En nuestro caso, desconocemos si los lugares del señorío estaban total o parcialmente amurallados, o si tenían puertas de entrada, ya que sólo disponemos de una escueta referencia de mediados del XVI en la que constan los gastos ocasionados en la reparación de la muralla, por lo que no podemos precisar la vigencia de esta azofra ni su amplitud y obligatoriedad. Sin embargo, los señores de la «Foia» y baronía de Llombai sí estaban muy interesados en las obras y reparaciones de su residencia, casas o castillo, asegurándose jornales gratuitos, tantos cuantos quisieran, para su construcción y mantenimiento; por ejemplo, a comienzos del siglo XV disponen: «que los dits moros sien tenguts de fer en la obra del castell lurs jornals segons que era menester e sens nenguna messio a senyor» (Catadau).

A mediados del citado siglo se insiste en esta azofra exclusivamente en Llombai y Alfarb. En Llombai, el mantenimiento del castillo por parte de los mudéjares suponía una fuerte carga ya que afectaba, de forma gratuita, tanto a los hombres como a sus animales, de manera que «si lo senyor volrra obrar en lo castell son tenguts los dits moros de darli tans jornals com mester haura axi ab besties com sens besties franch» (Llombai) ${ }^{122}$; y en Alfarb, tiene la particularidad de que es un trabajo remunerado «si lo senyor volrra obrar en lo castell es tengut cascun moro carrejar e tirar tot ço que menster haura ab sa mula e lo senyor als de dar I sou VI diners per jornal». En otros apartados se matiza el tipo de trabajo y su remuneración, según trabaje un hombre solo o acompañado de animal de carga, ya que «si lo senyor volrra a la dita obra hun moro ab son ase es tengut de darli un sou» o «si lo senyor volrra home forro a la dita obra

122. AHN: Sección Osuna, Leg. 1028. 
es tengut de darli per jornal huit diners». Conviene recordar que la implicación de los animales, afectaba de igual modo en Valencia, Aragón y Cataluña ${ }^{123}$.

Aun después de la forzosa conversión de los mudéjares, la azofra pervivió en el señorío, dándonos fe de ello algunos contratos de arrendamiento, como el de 1530 (cap. XVIII), en donde el señor se reserva los jornales «que los vehins, vassalls e habitadors de la dita Foia e baronía de Llombai e loch de aquella son tenguts e obligats fer donar al dit il lustre senyor don Francisco de Borja pera la obra del castell o castells casa e cases del senyor» ${ }^{124}$.

Como una prolongación de la reparación de los muros, aunque mucho más fácil de llevar a cabo que la fortificación de las murallas, era el aprovisionamiento de agua y leña al castillo. En su origen, el señorío que nos ocupa mantuvo vigente esta obligación en cuanto a la leña, obligación conmutada en Catadau (el año 1381 y 1401) y en Aledua por el pago de cierta cantidad de dinero fija anual ${ }^{125}$. En Alfarb se entregaba exclusivamente cuando el señor se hallaba en el señorío durante las pocas visitas que hacía a la baronía, siempre a su elección, siéndole más rentable cobrar en metálico en algunas ocasiones: »Deu la aljama de Alfarb per la lenya nou lliures»; o denominándola como azofra, $»$ son tenguts de dar lenya al senyor al castell tanta com mester haura stant hi lo senyor empero son avenguts ab lo senyor per la dita lenya per nou lliures (ço es) CLXXX sous $\eta^{126}$.

La leña era abundante en el señorío, pero su mediocre calidad hacía que su destino fuese el de ser utilizada como combustible ${ }^{127}$. Por tanto no es de extrañar que, en el siglo XVI, el señor mantuviese su derecho a ser abastecido de leña en su castillo o en su casa, o su conmutación en metálico, imponiendo a los moriscos continuar con una antigua azofra bajo la denominación de «dret de lenya«, de manera que: «per la lenya que eren obligats de portarla franca al senyor paguen cascun any en dines que no puja ni devalla nou lliures, es per concordia antiga, son pagadores a Sent Juhan y Nadal migerament VIIII lliures» (año 1540 Alfarb) o «per lo dret de la lenya que havia que dar a la casa del senyor... VIIII liures» o «al castillo del senyor VIIII liures» (años 1559 y 1563 Alfarb) $)^{128}$.

\section{2.- Transporte de productos agrícolas}

En la «Foia» y baronía de Llombai, las noticias más explícitas y antiguas referentes al acarreo de las rentas del señor se remontan a los siglos XIV y XV, bajo la denominación de azofra, en los términos siguientes: «empero es axi entes que les çoffres romanquen al senyor segons qu'es seguex ço es, que si.l senyor volrra quel porten

123. AHN: Sección Osuna, Leg. 722/6. Leg. 1028.

124. AHN: Sección Osuna, Leg. 587/32.

125. AHN: Sección Osuna, Leg 722/6/7 Carpeta 95/17 Leg. 722/62.

126. AHN: Sección Osuna, Leg. 1027/4 (año 1403).

127. Peris Albentosa, Tomás: Op. cit. vol. II, pág. 18.

128. AHN: Sección Osuna, Leg. 937/3. Leg. 1027/18. Leg. 1027/21. 
lo blat de les seues rendes e vi de les seues vinyes quatre legues entorn lo loch de Catadaur, los vasalls seus del loch de Catadaur sien tenguts de portar les dites coses a llur messio hoc encara a Xativa si lo senyor ho volrra» (Catadau, 1401) ${ }^{129}$. Los vasallos debían trasladar los productos cuatro o cinco leguas en torno al lugar de origen, ampliando esta azofra consistente en acarreo hasta Játiva, como acabábamos de citar, o hasta Valencia, para los de Alfarb, en el caso del transporte del vino. En ningún momento se indica que los productos fuesen llevados a la casa del señor, ya que su absentismo siempre fue significativo. Sin embargo se señalaron unos límites espaciales que aseguraban la entrega a sus representantes.

Los productos que fueron obligados a portear los vasallos de Catadau, el año 1401, fueron principalmente el trigo y el vino, mientras que, unos años después, la documentación más explícita recoge la obligación de acarrear, a la distancia ya indica$\mathrm{da}$, todos los frutos y derechos señoriales, mereciendo cita aparte el transporte del vino: «son tenguts tirar lo vi de la vinya que ells procuraran semblanment III o $\mathrm{V}$ llegues franchs» (Aledua) ${ }^{130}$.

El hecho de que en Llombai hubiese una población mixta nos permite comprobar y afirmar a qué comunidad afectaba cualquier imposición, ya que la documentación referente a este lugar lo hace de forma abierta y contundente: "son tenguts los moros de portar tots los blats esplets e altres coses de lurs drets quatre o cinch (sic) llegues entorn franch».

De forma esporádica, en las siete heredades compradas en Aledua por don Aymerich de Centelles, se añade la obligatoriedad de transportar la paja, perviviendo a comienzos del siglo XVI con ligeras modificaciones, y recordando en la concordia de 1505 que debian dar al procurador General y a otros oficiales tanta paja como necesitasen, cuando fueran al señorío «per faenes del senyor».

Unas décadas más tarde, esta imposición siguió afectando únicamente a los moriscos, entrando a formar parte de las condiciones de los arrendamientos: «Es més pactat e concordat entre les dites parts que tota la servitut de lo dit il.lustre senyor don Francisco de Borja com ha senyor de dita Foia e baronía e pera compellir e manar als moriscats vassalls de la dita Foia e baronía de portar per tanda los fruits e altres coses sues fins ha Valencia o a quatre legues entorn de la dita baronia sia compresa en lo dit arrendament e lo mateix mando e preheminencia los dits arrendador o arrendadors $\rangle^{i 31}$.

\section{3.- Viajes en general (Adzemblería)}

En el siglo XIV, don Ramón Castellá, en la carta referente a Llombai, indica la obligatoriedad que tienen los mudéjares de hacer viajes a su servicio, conceptuándolos como azofras y remunerando por separado a los hombres y a los animales de carga: «et

129. AHN: Sección Osuna, Leg. 722/62. Leg. 1028;.Leg. 584/1'14, carpeta 72/8.

130. AHN: Sección Osuna, Leg. 722/62. Leg. 1028.

131. AHN: Sección Osuna, Leg. 1028. Leg. 587/18. Leg. 587/32; GozÁLbez EsTEve, Elia: Análisis de un señorío valenciano..., Tesis cit. Tomo III, apéndice documental, pág. 117. 
que cascun moro, per cascun dia, que haja anar per lo dit en Ramon Castella fora lo dit loch per raho de çofra haja del dit en Ramon Castella deu diners et per cascuna mula o bestia major dehuyt diners et per cascuna bestia menor, ço es, asse quatorze diners per cascun dell (?) / que sia per affers del dit en Ramon Castella» ${ }^{132}$.

Así mismo, según se desprende de la carta puebla de Alfarb del XV, esta azofra tenía dos vertientes: acompañar al señor y transportar los productos. Dichos vasallos estaban obligados a acompañar a su señor en sus desplazamientos, con sus «adzembles», con la condición de que el señor se hallase presente en el lugar, lo cual suponía que sólo él podía beneficiarse de esta azofra, sin que ningún oficial subalterno pudiese requerir este servicio. Por su parte, el señor se encargaba del mantenimiento del vasallo y de su cabalgadura, remunerando su trabajo con un sueldo diario, «si lo senyor aura a fer viaje a aja abs adzembles son tenguts los moros de anar ab lo senyor present lo senyor, los ha de fer la messio els a dar ultra la messio delles e de la bestia un sou cascun jorn». Este tipo de servicio consistía, además, en realizar toda clase de mudanzas, transporte de correos, etc.

El ya citado absentismo señorial hace que, a renglón seguido, el documento recoja la modificación de la obligación de transporte de productos, y lo reduzca a una tanda por heredad, con animales o sin ellos, teniendo que pagar salario a los vasallos en caso de necesitar ampliar el servicio: «com la aljama de Alfarb fos tenguda de anar ab besties o sens besties alla hon lo senyor volgues franchs lo senyor los a feta gracia que no vol sino una tanda per heretat una ab bestia e altra sens bestia, e mes ne aura mester qu'ls aja allogar axi com si fos estranger». Insistiendo en esta azofra, un último apartado del mismo documento cita una concordia que redime el trabajo de acarreo por un pago anual: «fonse avenguts ab mi la aljama de Alfarp per les tandes, que eren moltes, e els n'e fet gracia e axi matex de la atzembleria mavien de donar, fonse abenguts ab mi per tos temps e donen me tots anys quinze e tene-ne carta».

Es de suponer, que más que implantar un cambio, en los anteriores capítulos de la carta puebla de Alfarb lo que se pretende es recordar a los vasallos moros en qué consistía este servicio y su antigüedad, antes de concluir en lo que realmente había quedado reducida la azofra, ya que, en la relación de las rentas de 1403 la aljama de Alfarb abonaba ya quince libras por el derecho de adzemblería ${ }^{133}$. La documentación posterior ratifica su pervivencia, tanto del derecho como de la concordia tasada en quince libras, «per les adzembles que eren obligats los de Alfarb de donar al senyor paguen cascun any en dines per concordia antiga a Sent Juan y Nadal migerament ${ }^{134}$.

Respecto a Llombai, el señor disponía de cuantos vasallos precisase, por lo que la documentación se detiene menos en analizar a qué labor se deben destinar, sin olvidar mencionar que los moros estaban obligados a «portar tots los blats, splets e altres coses de llurs drets quatre o cinch llegues entorn franchs». De forma muy similar, en Aledua,

132. AHN: Sección Osuna, Leg. 584/1/4, carpeta 72/8 (Llombai).

133. AHN: Sección Osuna, Leg. 722/6. Leg. 1028.

134. AHN: Sección Osuna, Leg. 588/2. Leg. 937/3. Leg. 1027/21. 
el transporte de productos agrícolas atañía a los mudéjares de la siguiente forma: «Item son tenguts de portar lo vi e tots los splets de llurs drets e fruits e palla IIII o V legues entorn franchs». Y en Catadau, posiblemente, la libertad de disponer de «un home forro» para realizar cualquier tipo de trabajo remunerado cubría la imposición de acarreo, pagando por ello un sueldo por día.

\section{4.- Jornales}

Los jornales impuestos a los vasallos del señorío suponían para el señor un importante ahorro económico, puesto que se aprovechaba de una parte de la fuerza de trabajo de sus enfiteutas gratis o a bajo precio. Esta azofra consistía en dar al señor un determinado número de jornales francos por heredad, o sin determinar su número si eran remunerados. Dicha obligación de realizar trabajos agrícolas gratuitos afectaba exclusivamente a los mudéjares, mientras que los remunerados, posiblemente, concernían también a los cristianos viejos, que al igual que en Aragón consiguieron conmutarlos por un pago en metálico.

Las tierras que el señor se reservó para su disfrute particular estaban dedicadas en gran parte a los viñedos, y de todos es sabido que la viña requiere abundante mano de obra, por lo que, lógicamente, se asignó un significativo número de jornales francos que le garantizasen su laboreo: «los dits moros del lloch de Catadaur sien tenguts de cavar en les vinyes del senyor o altres coses tres jornals per heretat, franchs e gratis a senyor» (Catadau, 1401) $)^{135}$.

El vino tenía fácil conservación, tanto para el consumo de la casa señorial como para su comercialización, por lo que los señores valencianos destinaban una parte importante de sus tierras a su cultivo, potenciando su extensión mediante tratos de favor, como podían ser las franquicias de partición durante un período de tiempo determinado. Por lo tanto, no es de extrañar que en los otros lugares del señorío, en el siglo $X V$, el señor se siguiese reservando tres jornales francos de sus vasallos mudéjares para la viña en Catadau y Llombai, y uno en Alfarb, mientras que en Aledua esta azofra se amplió a siete jornales francos por heredad, indicando que preferentemente fuesen destinados «per a cavar», lo cual nos hace suponer que tuviesen el mismo destino, los viñedos.

Mención aparte merece esta azofra en Alfarb, donde los mudéjares además tenían obligaciones y faenas añadidas relacionadas con la elaboración y transporte del vino: «son tenguts de veremar e tirar la verema e colçinar e lavar gerres e portar lo vi a Valençia o quatre llegues en torn tot franch», así como otros jornales francos destinados a diversos cultivos: «son tenguts los moros, si lo senyor volrra fer laurada, de fer al

135. AHN: Seccion Osuna, Leg. 722/6². Aledua: «Son tenguts a cavar set jornals per heretat o a fer ço que 10 senyor ne volrra cascum any una vegada». Aparte, en la relación de Llombai se precisa que los moros de Aledua que tenían tierras de cristianos en Llombai debian hacer tres jornales francos anuales,al igual que los mudéjares de Llombai. 
senyor jovada axi que li lauraran un jornal per heretat e a segar altre jornal cascun any una vegada franch al senyor $\rangle^{136}$.

Evidentemente, las citas anteriores aportan una información muy valiosa en cuanto a la labor que los mudéjares debían realizar en las faenas agrícolas de forma gratuita: cavar, segar o vendimiar, así como la limpieza de los utensilios imprescindibles para la elaboración del vino, y su acarreo a Valencia o a cuatro leguas en torno al marquesado. El número excesivo de jornales y la reducida reserva señorial indujeron a realizar varias concordias, entre ellas la de 1505 , en la que se conmutaba la obligación por «quinze diners per cascun jornal de les dites aljames e singulars de aquelles son tenguts obligats fer per lo senyor cascun any de home forro», y por cada jornal que estaban obligados a realizar de labranza «dos sous e mig». Posiblemente, su finalidad también era paliar los perjuicios ocasionados al señor por la negligencia con que eran efectuados los trabajos, sin descartar que éstos cada vez le eran menos necesarios y que su liquidez económica atravesaba por un mal momento.

Por su parte, las aljamas se comprometieron a cumplir lo acordado, haciéndose responsables de obligar a los vasallos a realizar los jornales estipulados, siempre y cuando, una vez pasada la Navidad, quedasen aun jornales pendientes: «E mes prometens obligam que sis jornals eran deguts a sa Il-lustre senyoria fins al dit dia de Nadal que tots los que seran tenguts e obligats de fer a aquells dites aljames e singulars de aquelles los faran tota hora quant los ministres e officials de sa il-lustre senyoria volrran e elegiran». Los jornales que no se realizaban en la época adecuada perjudicaban la producción agrícola; y según los datos disponibles, parece deducirse que así ocurría. Pero lo que nos interesa destacar es que estas labores agrícolas habían dejado de tener un interés real en un señorío con una reserva limitada y que, en definitiva, respondían a una situación anterior.

Respecto a los jornales remunerados, el señor no estaba dispuesto a renunciar a ellos, por lo que se reservó tantos jornales como quiso, tasando el salario según el lugar: en Catadau, el año 1401, por un hombre solo, doce dineros; un hombre con su bestia, dieciocho dineros; y un hombre con su asno, quince dineros. Esta situación se mantuvo con el lógico incremento en la remuneración, por lo que en las cartas pueblas del XV puede disponer, además, de un hombre libre para dedicarlo al trabajo que precisase, por el precio de un sueldo; $y$ de todas las mulas que le fuesen necesarias, por un sueldo y seis dineros.

En Llombai y Alfarb el señor gozaba de plena autonomía para disponer de cuantos jornales quisiera, siempre que los pagase. La amplitud del derecho queda elocuentemente reflejada en el siguiente párrafo referente a Llombai: «son tenguts, que si lo

136. AHN: Sección Osuna, Leg. 1028; Leg.1028; Leg. 587; BurNS, Robert I: El colonialisme... Op.cit., pág. 223; DiCCIONARIO ALCOVER, pág. 779. Jovada «Extensió de terre que llaura normalment un parell de baus en un dia». CisCAR PAllares, Eugenio: La Valldigna.., Op. cit., pág. 98. Cuando habla «dels Rafalins» adquiridos por compras los señala como lugares en donde sus vecinos están a merced de los señores, los cuales pueden «despedir o llansarne aquells que li plaura segons que se acostuma en la present Regne de Valencia en lo llochs que dihuen rafalins..» 
senyor volria tans jornals com li plaura, e a quina faena volrra anant a tanda fer los dits jornals donant lo senyor un sou per jornal a ome forro o un Real de Valençia ab cavalcaduras ${ }^{137}$. Y en Alfarb, tras exponer la ya citada obligación de dar un jornal franco al año para cavar la viña, se añade: «e si lo senyor aura mester mes jornals, son tenguts de darli tans com 1,in plaura pero lo senyor los a dar hun, sou quatre diners per jornal mes no pot lo senyor triar aquells moros que li plaura». Tan amplia autonomía para elegir o rechazar al vasallo que deseara era un privilegio que perdió el señor a partir de este momento. A comienzos del siglo XVI (1514), en las notas marginales ya citadas, hallamos que las obligaciones que afectaban con jornales francos a Alfarb, a excepción del jornal franco dedicado a la viña, eran conmutados por un pago en metálico: «totes aquestes servituts pagen per concordia a beneplacit del senyor set lliures sis sous» ${ }^{138}$.

Los demás lugares del señorío también quedaron exentos de esta azofra siempre y cuando fuese gratuita, pero en el caso de las remuneradas el señor se reservaba su derecho, conmutando los jornales por un pago fijo anual: en Llombai por cuatro libras, dieciocho sueldos y ocho dineros; en Catadau, diez libras diecinueve sueldos y nueve dineros; y en Aledua los siete jornales francos anuales se conmutaron por cinco libras y tres sueldos.

De lo expuesto hasta aquí puede deducirse que los jornales remunerados tenían una variada gama de precios según su dedicación, diferenciando si los realizaba un hombre solo o ayudado por su cabalgadura; y aún en este último caso, se matizaba y se tasaba de diferente forma según el tipo de animal que ejecutaba el trabajo. Hemos de hacer notar que los jornales francos no afectaban a las cabalgaduras, si exceptuamos los de labrar en Alfarb, y que los jornales remunerados dedicados a las obras estaban peor pagados que los dedicados a las faenas agrícolas. En resumen, pese a esta minuciosa descripción de cuántos, cómo y dónde debían realizarse los jornales que obligaban a los mudéjares, el deterioro de las costumbres, la poca diligencia de los subordinados señoriales y la demanda de las aljamas, tendentes a reducir estas prestaciones, dio lugar a las concordias a las que hemos hecho alusión líneas atrás, sin olvidar el interés señorial en aumentar los ingresos en dinero en lugar de tanto servicio personal ya innecesario.

Posteriores relaciones de rentas del siglo XVI nos confirman la continuidad de la conmutación en metálico de la azofra.

\section{CUADRO NVII ${ }^{139}$}

\begin{tabular}{|c|c|c|c|c|}
\hline AÑOS & LLOMBAI & CATADAU & ALFARB & ALEDUA \\
\hline 1539 & 3 L. 18 s. 8 d. & 10L. 19s.11d. & & 5 L. 13s. \\
\hline $1540-43$ & 4 L. 18 s. 8 d. & 10L. 19s. & 7L.6s. & 5 L. 14 s. \\
\hline 1559 & 4 L. 18 s. 6 d. & 10L. 19s. & & 5 L. 14 s. \\
\hline 1563 & 3 L. 18 s. 6 d. & 10L. 19s.11d. & 7L.6s. & 5 L. 4 s. 4 d. \\
\hline
\end{tabular}

137. AHN: Sección Osuna, Leg. 1028.

138. AHN: Sección Osuna, Leg. 587/18.

139. AHN: Sección Osuna, Leg. 588/2. Leg. 937/3. Leg. 1027/18. Leg. 1027/21. 
Inserta en el arrendamiento de 1607, aparece la siguiente nota: «durante el arrendamiento se reservan para su excelencia cada anyo quarenta tandas que los vasallos son tenidos y obligados a dar cada anyo al senyor de dicho marquesado». La ausencia de mención alguna, en este párrafo, a la comunidad sobre la cual recaía la obligación, nos hace suponer que parte de los jornales remunerados atañeron también a los cristianos viejos como simples corveas; pero la hipótesis queda un poco en el aire por la ambigüedad de la cita. Así mismo, tampoco podemos asegurar que dichas tandas de jornales se realizaran efectivamente, o si era suficiente con pagar el precio acordado por ellas.

\section{5.- La hilaza}

Hilar para el señor una cierta cantidad anual es otra de las azofras que los señores de la «Foia» y baronía de Llombai no olvidan incluir en sus rentas desde el inicio del señorío, con muy poca oscilación y variedad de unos lugares a otros, afectando tan sólo a la comunidad musulmana. Durante el siglo XV los mudéjares estaban sujetos a entregar a su señor las siguientes cantidades por heredad:

Llombai: 1 libra de lino o 2 de estopa.

Alfaro: 1 libra de lino.

Aledua: 1 libra de lino.

Catadau: 1 libra de lino o 2 de estopa ${ }^{140}$.

Pero la obligación implicaba también a los terratenientes denominados en el señorío «xamesos», los cuales debían satisfacer esta imposición o azofra del mismo modo que el resto de los mudéjares o moriscos, con algunas variantes según el lugar de su ubicación. Por ejemplo, los de Llombai y Catadau debían hilar «una 1liura de lli o dues d'estopa cascun any»; los de Alfarb «una lliura de lli o una lliura d'estopa cascun any»; y los de Aledua «una lliura de filaça cada any».

A mediados del XV, se precisa «Item si hi a xamenços son tenguts de pagar cascun any tres sous quatre diners e fer la filaça damunt dita», o sea, una libra de lino por cada heredad. En Aledua: «Es tengut cascun xames de pagar tres sous quatre diners e axí matex de fer la filaça damunt dita cascun any». También, los «xamensos» de Alfarb debían hilar anualmente lo mismo que los demás vasallos de este lugar; y en Catadau se indica: «Es tengut cascu xamens de pagar tres sous quatre diners e aixi matex de fer la filaça damunt dita cascun any». A partir de mediados del siglo XVI las rentas analizadas dejan de citar la presencia de «xamesos» y su aportación (1542).

Tal y como hemos indicado en otras ocasiones, la tranformación de esta azofra en una paga anual tiene como origen la Concordia de 1505 , considerada por parte de la aljama como favorable para sus intereses. En ella se acordó pagar anualmente a don Juan de Borja y a sus sucesores 17 dineros por cada libra de hilaza, obligando particular y universalmente a los mudéjares, a través de sus aljamas, a cumplir lo acordado.

140. AHN: Sección Osuna, Leg. 1028. 
Posteriores acuerdos, que quedan registrados en notas marginales en las cartas pueblas del XV, transformaron esos 17 dineros por cada libra de hilaza, en una cantidad fija anual, afectando de diferente forma según el lugar:

Llombai: «tenen per concordia a beneplasit II lliures».

Aledua : «paguen per lo dret de la filaça II lliures IIII sous IIII [diners]».

Catadau: «paguen per concordia per la filaça V lliures XIIII sous X dines».

Alfarb : «tenen hui per concordia III lliures III sous II diners $\rangle^{141}$.

Los ingresos provenientes de la conmutación de la hilaza por un pago monetario permanecieron casi inmutables a lo largo del siglo, según se desprende del cuadro que sigue:

\section{CUADRO No VIII ${ }^{142}$}

\begin{tabular}{|c|c|c|c|c|}
\hline Años & Lombai & Catadau & Alfarb & Aledua \\
\hline 1539 & 2 L. $18 \mathrm{~d}$. & 5. L. 13 s. $9 \mathrm{~d}$. & 3 L. $7 \mathrm{~s}$. & 2 L. 4 s. 4 d. \\
\hline $1540-43$ & 2 L. $10 \mathrm{~d}$. & 5 L. 13 s. 9 d. & 3 L. 7 s. 2 d. & 2 L. 4 s. 4 d. \\
\hline 1559 & $2 \mathrm{~L} .6 \mathrm{~d}$. & 5 L. 13 s. 9 d. & $3 \mathrm{~L} .7 \mathrm{s.} 2 \mathrm{~d}$ & 2 L. 4 s. 4 d. \\
\hline $1560-63$ & 2 L. $10 \mathrm{~d}$. & 5 L. 14 s. 9 d. & 3 L. 7 s. 2 d. & \\
\hline
\end{tabular}

\section{6.- Suministro de la despensa señorial}

Dentro del capítulo de las azofras, la documentación incluye prestaciones que no son en trabajo pero que suponían un ingreso importante a las arcas señoriales. Tal es el caso de la imposición que pesaba sobre los mudéjares, más tarde moriscos, de abastecer la despensa señorial con productos francos o a precio de tasa.

En el siglo XIV las aves de corral son tasadas en Llombai de la siguiente forma: «sia tengut de donar et pagar per cascun parell de gallines dos sous, per cascun parell de polles setze diners, per cascun parell de polls / huyt diners»; pero es a partir del siglo XV cuando la documentación nos facilita una información más completa, la cual queda reflejada en el siguiente cuadro.

\section{CUADRO N IX}

Productos sujetos a tasación y precio impuesto ${ }^{143}$

\begin{tabular}{|c|c|c|c|}
\hline \multicolumn{2}{|c|}{ CATADAU } & ALFARB \\
\hline Huevos & $\mathbf{1 4 0 1}$ & Mediados del siglo XV & Mediados del siglo XV \\
\hline Gallinas & 3 por 1 dinero. & 3 por 1dinero & $\begin{array}{c}\text { 3 por 1 d. (tanto si está el señor } \\
\text { como si no). }\end{array}$ \\
\hline Pollos & 12 dineros & 2 por 2 sueldos & $\begin{array}{c}2 \text { por } 1 \mathrm{~s} \text {. «gordas pera son } \\
\text { menjar». }\end{array}$ \\
\hline
\end{tabular}

141. AHN: Sección Osuna, Leg. 1028 (notas marginales).

142. AHN: Sección Osuna, Leg. 588/2. Leg. 937/3. Leg. 1027/18. Leg. 1027/21.

143. AHN: Sección Osuna, Leg. 722/6². Leg. 1028. Leg. 722/6. 


\begin{tabular}{|c|c|c|c|}
\hline \multirow{2}{*}{ Uvas } & 1401 & Mediados del siglo XV & ALFARB \\
\hline & & & $\begin{array}{c}\text { Las que quiera el señor para } \\
\text { comer él y sus acompañantes } \\
\text { en tiempo de la cosecha más } \\
\text { una cesta de verema. }\end{array}$ \\
\hline Cabritos & & & $\begin{array}{c}\text { «pot pendre pera son menjar } \\
\text { uno a 1 sou». }\end{array}$ \\
\hline «Vedell» & & & $\begin{array}{c}\text { «pot pendre pera son menjar } \\
\text { uno per cinch sous» }\end{array}$ \\
\hline «Llocada» & & & $\begin{array}{c}\text { Deben dar al señor un pollo por } \\
\text { «llocada» y si lo prefiere por } \\
\text { cada pollo 4 d. }\end{array}$ \\
\hline Pollas & & 2 por 1 sueldo 4 dineros & $\begin{array}{c}\text { 2 por 10 dineros, con la condi- } \\
\text { ción de que sean gordas. }\end{array}$ \\
\hline Mulas & & «Tantes com volrra per Is. & \\
\hline
\end{tabular}

Desconocemos si esta azofra afectó en este período a Aledua, ya que la entrega de ciertas gallinas, pollos y huevos posiblemente pasaron a engrosar la cantidad que consideramos como peita; no obstante, en las siete heredades compradas por don Aymerich de Centelles, se dice que «si lo senyor volrra lenya, ne gallines, ne polls, ne hous pot ho pendre en la manera que ells ho tenen del dit senyor». Una nota marginal inserta en el documento anterior, con fecha de 1514, entorpece más que esclarece el conocimiento del destino que tuvo esta azofra en Aledua, pues sólo recoge una conmutación en metálico referente a las gallinas, sin hacer mención a los otros productos alimenticios sujetos a precio de tasa: «concordia feta ab Joan Garcia pagen per les gallines 1 sou 6 (diners)».

De forma más explícita, en Catadau permutarán la prestación mediante concordia, quedando como beneficiario Joan García: «pagen per concordia a Joan Garcia II sous III diners per casa a beneplacit del senyor», y en Alfarb: «per totes aquestes servituts de gallines cabrits e hous ha feta concordia Joan Garcia ab los dits vasalls que puguen hun real per casa e no sien obligats a donar les dites coses e aço durant la ausensia de sa senyoria e seu beneplacit».

Alfarb es el lugar del señorío que con mayor rigor se vio afectado por esta azofra. El suministro de productos francos o a bajos precios era gravado con la obligación de entregar a la casa señorial, además de una cesta de uvas, todo lo que necesitase el señor o sus invitados en tiempo de la cosecha. Dentro de esta ampliación de la azofra se contemplaba el tener que venderle, a precio de tasa, un cabrito o un «vendell», siempre que el señor se hallase en el lugar ${ }^{144}$. La presencia del señor condicionaba en muchos casos la entrega de estos suministros a los que nos estamos refiriendo. No obstante, inde-

144. AHN: Sección Osuna, Leg. 1028. Leg. 722/6. 
pendientemente de si el señor se hallaba o no presente, debía entregarse un pollo por «llocada» o su conmutación en metálico (4 dineros), así como huevos al precio fijado.

Es difícil precisar si los mudéjares de Llombai estaban gravados con esta azofra en el siglo XV, ya que las rentas de mediados del XVI la mencionan como una nueva imposición para los moriscos de este lugar, al parecer directamente conmutada por concordia en los siguientes terminos: «paguen per lo nou dret los moricats de Llombai per la obligasio que tenen de donar al senyor gallines, polles, polls y ous a certs preus paguen cascun any en diners al senyor a concordia feta a beneplacit de sa senyoria de dos sueldos quatre diners cascuna any que per setanta cases que ya munten 8 lliures 18 sous 8 diners».

La azofra quedó conmutada en un pago en metálico que afectaba por casa habitada, con diferente tasación según el lugar: Aledua y Alfarb un sueldo seis dineros, y Llombai y Catadau dos sueldos cuatro dineros. La relación de las rentas del XVI recoge los ingresos anuales provinientes de la conmutación de esta azofra según se expone en el siguiente cuadro:

CUADRO N. ${ }^{\circ} \mathrm{X}$

Tandas de gallinas ${ }^{145}$

\begin{tabular}{|c|c|c|c|c|}
\hline AÑO & LLOMBAI & CATADAU & ALFARB & ALEDUA \\
\hline 1539 & 9 L. $11 \mathrm{~s} .4 \mathrm{~d}$. & $8 \mathrm{~L} .8 \mathrm{~s}$. & $3 \mathrm{~L} .16 \mathrm{~S}$. & $2 \mathrm{~L} .5 \mathrm{~s}$. \\
$1540-43$ & $8 \mathrm{~L} .18 \mathrm{~s} .8 \mathrm{~d}$. & $8 \mathrm{~L} .8 \mathrm{~s}$. & $3 \mathrm{~L} .16 \mathrm{~s} .6 \mathrm{~d}$. & $2 \mathrm{~L} .8 \mathrm{~s}$. \\
1559 & 8 L. $17 \mathrm{~s} .4 \mathrm{~d}$. & & $4 \mathrm{~L} .10 \mathrm{~s}$. & $2 \mathrm{~L} .12 \mathrm{~s}$. \\
$1560-63$ & 9 L. $4 \mathrm{~s}$. & 9 L. $16 \mathrm{~s}$. & 4 L. $17 \mathrm{~s} .6 \mathrm{~d}$. & 2 L. $1 \mathrm{~s}$. \\
\hline
\end{tabular}

De forma aislada, en la renta de 1539 se confirma la aportación anual y por casa que afectaba a Alfarb «per lo dret de llocada». Este derecho fue incluido en el acuerdo establecido con el señor referente a las aves y los huevos, al ser conmutado por cuatro dineros. No obstante, el arrendatario de los últimos diez años no tuvo en cuenta dicha concordia y cobró de más, incurriendo en un error que se comprometió a subsanar en los siguientes términos: «pongo en cuenta onze libras trece sueldos quatro dineros los quales examinada mi cuenta hallo haver recibido durante el año 1530 hasta el presente año 1539 a saber es 13 sueldos y 4 dineros cada año por razón de quatro dineros por cada casa de dicho lugar poblada o despoblada es obligada de dar y paguar al senyor por lo derecho de las loquas y puesto que se pretende por parte de la aljama del dicho loguar que los dichos quatro dineros por casa estan conprendidos en la concordia hecha con su senyoria de las haves y huevos (ilegible) pues hallo yo haverlas recibido me haguo aquí deudor dellas por setenta y una casa que hay en en dicho lugar asi pobladas

145. AHN: Sección Osuna, Leg. 588/2. Leg. 937/3. Leg. 1027/18. Leg. 1027/21. 
como despobladas suben los dichos quatro dineros en los dichos dies años las dichas 11 libras 8 sueldos 8 dineros ${ }^{146}$.

Las rentas de años sucesivos no recogen el ingreso procedente de las «llocadas», respetando así el arrendador lo acordado; pero a partir de 1560 la renta de Alfarb incluye un ingreso un tanto confuso: «per el dret dels pollastres que solíen (donar) de cada llocada un poll», sin que podamos determinar si se trataba del mismo impuesto ${ }^{147}$.

En fin, a nivel global, la «Foia» y baronía de Llombai se nos presenta en los siglos XIV, XV y XVI como un señorío en donde su población musulmana permite a los señores mantener unos ingresos de tradición islámica, a la vez que obligan a la comunidad vencida a coexistir con las nuevas imposiciones.

En líneas generales, cuando una situación de crisis desborda los límites habituales y se manifiesta en diferentes aspectos de la vida económica y social, hay que buscar la concurrencia de varias causas que la provocan. Estas fueron abundantes en el siglo XV y XVI en el Reino de Valencia y, para el caso que nos ocupa, podemos asegurar que la «Foia» y baronía de Llombai fue un claro exponente en donde cargas señoriales, acontecimientos sociopolíticos y convivencia de dos culturas distintas, dieron como resultado unas rentas acordes con su trayectoria histórica, y el medio físico en que se desarolla.

Las diferencias entre campesinos cristianos viejos y campesinos mudéjares estaban lejos de ser imaginarias. Si bien es cierto que debemos admitir que la historiografía ha exagerado esas diferencias, también lo es que éstas son muy marcadas cuando, por ejemplo, abordamos el contenido de las azofras; sin que en ningún momento pretendamos valorar si esta fiscalidad le era rentable al señor. Lo que sí es un hecho indiscutible es la estrecha dependencia de los vasallos mudéjares con quienes fueron sus señores, relación que plantea situaciones peculiares y atrayentes, pero también discriminatorias.

Otro asunto importante referente a la fiscalidad de este periodo y los cambios experimentados fueron las concordias entre el señor y sus vasallos, que vinieron propiciadas en la mayoría de los casos tanto por la presión de los vasallos como por las vicisitudes económicas de los señores. Presumiblemente, el señorío también debió sufrir el endurecimiento fiscal propio del siglo XIV, lleno de calamidades y dificultades; aunque aquí, el señor optó por unos ingresos monetarios que tuvieron muy poca duración, pero que nos anticipan cuál iba a ser la evolución de las rentas. Pero sobre todo, los señores de la «Foia» y Baronía de Llombai, a partir del siglo XV, se afanaron en mantener una renta que les fuese favorable, siendo siempre su primera fuente de ingresos las particiones, seguida por los censos, los monopolios y los luísmos, y a gran distancia, por las azofras, que eran unas imposiciones muy especiales por su connotación servil.

Para valorar el peso de la presión fiscal no está de más recordar la necesidad de distinguir entre la teoría y la realidad, pues en el marquesado de Llombai regía la

146. AHN: Sección Osuna, Leg. 588/2.

147. AHN: Sección Osuna, Leg. 10287/21. 
costumbre y con el paso del tiempo se apartaba del punto inicial, o sea de las cartas pueblas, beneficiando principalmente a los cristianos viejos. En la práctica, se hace difícil precisar si los mudéjares-moriscos cumplieron con las obligaciones que estos documentos recogen; aunque por sus quejas y reticencias parece ser que sí. Por tanto, en nuestro caso, podemos aplicar las palabras de Cardaillac, cuando afirma que los moriscos, cargados con severas particiones y duras obligaciones, como eran las azofras, fueron forzados a una conversión que, aunque no deseada, les hizo abrigar esperanzas de mejoras económicas que les igualase con los cristianos viejos; esperanzas que se vieron defraudadas debido, fundamentalmente, a la actitud de sus señores. Actitud que, según Tulio Halperin Donghi ${ }^{148}$, puso de relieve la doble intencionalidad señorial que hacía inviable esa igualdad, porque se pretendía asimilar a los moriscos al cuerpo de la nación cristiano-valenciana sin alterar la estructura social del reino, la cual se apoyaba en una división jerarquizada entre cristianos viejos y moriscos.

La coacción de la conversión forzosa provocó graves dudas sobre la percepción de la renta en el señorío; los moriscos del marquesado reclamaron, incansablemente, ser tratados fiscalmente como los demás cristianos, tal y como se les había prometido, aunque fuese veladamente. Pero estas demandas fueron desoídas por el duque de Gandía, teniendo como respuesta, por parte de dichos moriscos, una persistente oposición a seguir tributando como cuando eran mudéjares, enfrentamientos que canalizó la comunidad discriminada a través de fraudes, simulaciones y negativas tales como, por ejemplo, cabrevar o pagar luísmos.

Finalmente nos hemos de preguntar hasta qué punto este cúmulo de tributaciones y su evolución pesó al redactar las cartas de población del XVII en el señorío. Siempre con las limitaciones que toda generalización impone, podemos apuntar que esencialmente la expulsión de los moriscos alteró la política económica anterior, introduciendo modificaciones y cambios más coherentes y racionales. Pero centrándonos nuevamente en el marquesado, podemos afirmar que el peso de la fiscalidad a través de las particiones se aplicó de forma implacable sobre la población cristiana, que por la fuerza de la costumbre había estado exenta en la época mudéjar. Los Borja lograron conservar unas particiones altas, frenando de esta forma el impacto de una galopante erosión.

148. HALPERIN DONGH, Tulio: Un conflicto nacional..., Op. cit. 